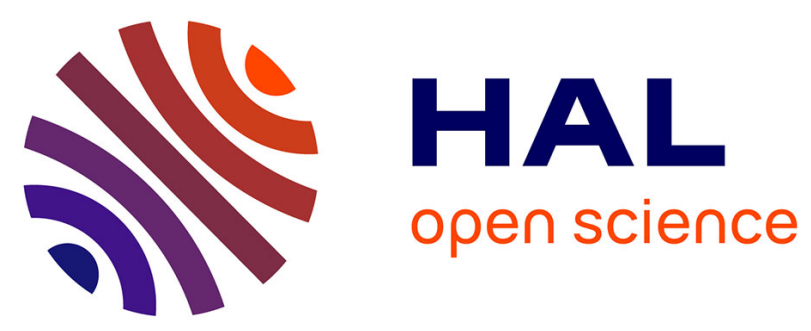

\title{
Molybdenum Complexes Bearing the Tris(1-pyrazolyl)methanesulfonate Ligand: Synthesis, Characterization and Electrochemical Behaviour
}

Chiara Dinoi, M. Fátima C. Guedes da Silva, Elisabete C B A Alegria, Piotr Smoleński, Luísa M D R S Martins, Rinaldo Poli, Armando J L Pombeiro

\section{To cite this version:}

Chiara Dinoi, M. Fátima C. Guedes da Silva, Elisabete C B A Alegria, Piotr Smoleński, Luísa M D R S Martins, et al.. Molybdenum Complexes Bearing the Tris(1-pyrazolyl)methanesulfonate Ligand: Synthesis, Characterization and Electrochemical Behaviour. European Journal of Inorganic Chemistry, 2010, 2010 (16), pp.2415-2424. 10.1002/ejic.201000018 . hal-03177784

\author{
HAL Id: hal-03177784 \\ https://hal.science/hal-03177784
}

Submitted on 23 Mar 2021

HAL is a multi-disciplinary open access archive for the deposit and dissemination of scientific research documents, whether they are published or not. The documents may come from teaching and research institutions in France or abroad, or from public or private research centers.
L'archive ouverte pluridisciplinaire HAL, est destinée au dépôt et à la diffusion de documents scientifiques de niveau recherche, publiés ou non, émanant des établissements d'enseignement et de recherche français ou étrangers, des laboratoires publics ou privés. 


\section{Molybdenum complexes bearing the tris(1-pyrazolyl)methanesulfonate}

\section{ligand: synthesis, characterization and electrochemical behaviour}

Chiara Dinoi, ${ }^{[a, b]}$ M. Fátima C. Guedes da Silva, ${ }^{[a, c]}$ Elisabete C. B. A. Alegria, ${ }^{[a, d]}$ Piotr

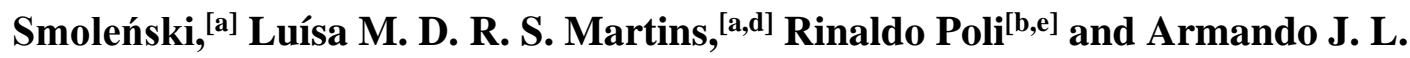

\section{Pombeiro $^{*[a]}$}

${ }^{a}$ Centro de Química Estrutural, Complexo I, Instituto Superior Técnico, TU Lisbon. Av. Rovisco Pais, 1049-001 Lisbon, Portugal. E-mail: pombeiro@ist.utl.pt

${ }^{b}$ CNRS; LCC (Laboratoire de Chimie de Coordination); Université de Toulouse; UPS, INPT; 205, route de Narbonne, F-31077 Toulouse, France.

${ }^{c}$ Universidade Lusófona de Humanidades e Tecnologias, ULHT Lisbon, Campo Grande 376, 1749-024 Lisboa, Portugal.

${ }^{d}$ Departamento de Engenharia Química, ISEL, R. Conselheiro Emídio Navarro, 1950-062 Lisboa, Portugal.

${ }^{e}$ Institut Universitaire de France, 103, bd Saint-Michel, 75005 Paris, France 


\section{Graphical Abstract}

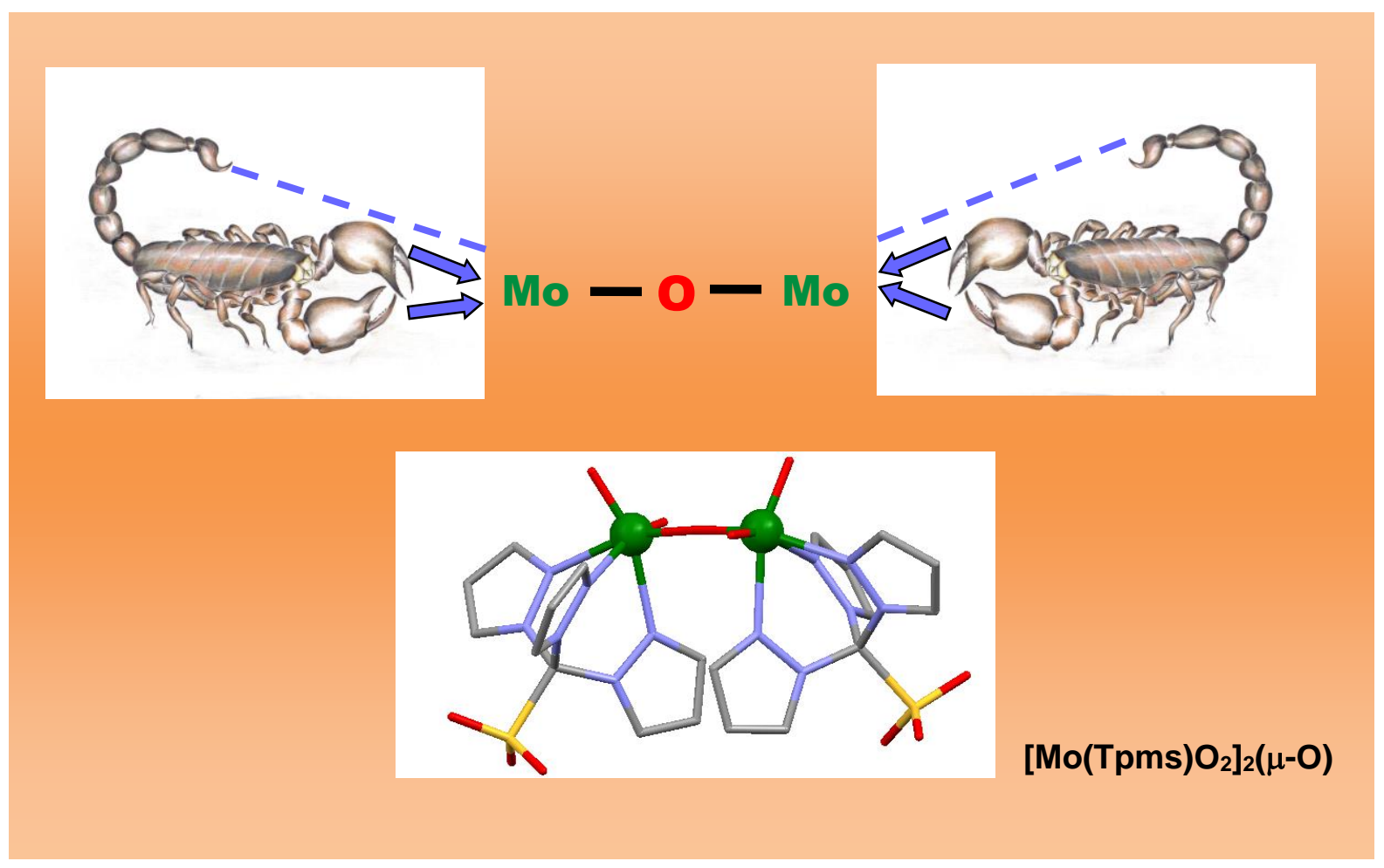

Both low and high oxidation state water soluble Mo complexes bearing the tris(1pyrazolyl)methanesulfonate (Tpms) ligand were prepared. High valent dinuclear Tpms-oxoMo species were obtained by oxidation with air of $\left[\mathrm{Mo}(\mathrm{Tpms})(\mathrm{CO})_{3}\right]$ or of derived 7coordinate halogenated and hydride species.

Key Topic: Mo complexes bearing Tpms 


\section{Summary}

The tris(1-pyrazolyl)methanesulfonate lithium salt LiTpms $\left[\mathrm{Tpms}=\mathrm{SO}_{3} \mathrm{C}(\mathrm{pz})_{3}{ }^{-}\right]$reacts with $\left[\mathrm{Mo}(\mathrm{CO})_{6}\right]$ in refluxing NCMe yielding $\mathrm{Li}\left[\mathrm{Mo}(\mathrm{Tpms})(\mathrm{CO})_{3}\right](\mathbf{1})$ which, upon crystallization from thf, forms the coordination polymer $\left[\mathrm{Mo}(\mathrm{Tpms})(\mathrm{CO})_{2}(\mu-\mathrm{CO}) \mathrm{Li}(\mathrm{thf})_{2}\right]_{\mathrm{n}}(\mathbf{2})$. Reaction of $\mathbf{1}$ with $\mathrm{I}_{2}, \mathrm{HBF}_{4}$ or $\mathrm{AgBF}_{4}$ yields $\left[\mathrm{Mo}(\mathrm{Tpms}) \mathrm{I}(\mathrm{CO})_{3}\right] \quad(\mathbf{3}), \quad\left[\mathrm{Mo}(\mathrm{Tpms}) \mathrm{H}(\mathrm{CO})_{3}\right]$ (5) or $\left[\mathrm{Mo}(\mathrm{Tpms}) \mathrm{O}_{2}\right]_{2}(\mu-\mathrm{O})$ (7), respectively. The high oxidation state dinuclear complexes $[\mathrm{Mo}(\mathrm{Tpms}) \mathrm{O}(\mu-\mathrm{O})]_{2} 4$ and $[\mathrm{Mo}(\mathrm{Tpms}) \mathrm{OCl}]_{2}(\mu-\mathrm{O}) \mathbf{6}$ are formed upon exposure to air of solutions of $\mathbf{3}$ and $\mathbf{5}$, respectively. Compounds 1-7, which appear to be the first tris(pyrazolyl)methanesulfonate complexes of molybdenum to be reported, were characterized by IR, ${ }^{1} \mathrm{H}$ and ${ }^{13} \mathrm{C}$ NMR spectroscopies, ESI-MS, elemental analysis, cyclic voltammetry and, in the cases of LiTpms and compounds $2,4 \cdot 2 \mathrm{CH}_{3} \mathrm{CN}, \mathbf{6} \cdot 6 \mathrm{CHCl}_{3}$ and 7 , by X-ray diffraction analyses. LiTpms forms a 1D polymeric structure, i.e. [LiTpms $]_{\mathrm{n}}$, with Tpms as a tetradentate $\mathrm{N}_{2} \mathrm{O}_{2}$ chelating ligand that bridges two Li cations with distorted tetrahedral coordination. 2 is a $1 \mathrm{D}$ coordination polymer where Tpms acts as a bridging tetradentate $\mathrm{N}_{3} \mathrm{O}$ ligand and each $\mathrm{Li}(\text { thf })_{2}{ }^{+}$moiety is coordinated by one bridging $\mathrm{CO}$ ligand and by the sulfonyl group of a contiguous monomeric unit. In 4, 6 and 7 the Tpms ligand is a tridentate chelator either in the NNO (in 4) or in the NNN (in 6 and 7) fashion. Complexes 1, 3 and $\mathbf{5}$ exhibit, by cyclic voltammetry, a single electron oxidation at oxidation potential values indicating that the Tpms ligand has an electron-donor character weaker than that of cyclopentadienyl.

Keywords: Molybdenum, tris(1-pyrazolyl)methanesulfonate ligand, scorpionate, crystal structure, carbonyl complexes, electrochemistry, high oxidation state. 


\section{Introduction}

Facially coordinating tridentate nitrogen donor ligands have experienced a rapid development in the last years, and namely tris(pyrazolyl)borates constitute a highly successful type of ligands, forming complexes with applications in various fields such as catalysis, metal extraction and bioinorganic modelling. ${ }^{[1-11]}$ Their success results largely from the ability to tune steric ${ }^{[1,12]}$ and electronic ${ }^{[12,13]}$ properties. Since Trofimenko synthesized the poly(1pyrazolyl)borate ligands, ${ }^{[14,15]}$ they have experienced a growing application, becoming the most commonly used tripodal ligands. ${ }^{[1-24]}$ However, they have the disadvantage of being insoluble in water and unstable towards hydrolysis. ${ }^{[1,10]}$ In order to obtain complexes that are soluble and stable under physiological conditions and that could therefore be used as better enzyme models, Kläui and co-workers reported ${ }^{[25]}$ the synthesis of the novel tris(1pyrazolyl)methanesulfonate (Tpms) ligand that relates to the conventional hydrotris(1pyrazolyl)borate (Tp) species (Figure 1). Both can act as a monoanionic, $\mathrm{C}_{3 \mathrm{v}}$-symmetrical Ndonor ligands, but instead of the boron hydride unit of Tp, Tpms bears a methanesulfonate group which affords good stability towards hydrolysis and increased solubility in polar solvents, e.g. water and methanol.

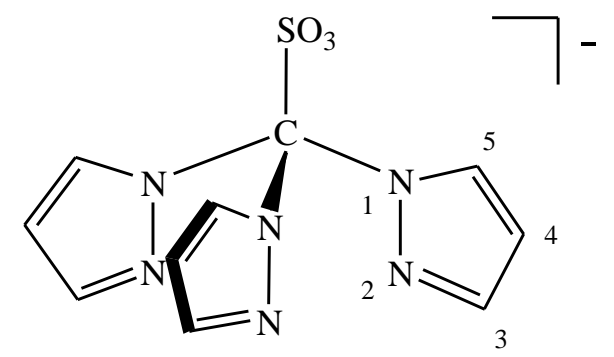

Tris(1-pyrazolyl)methanesulfonate (Tpms)

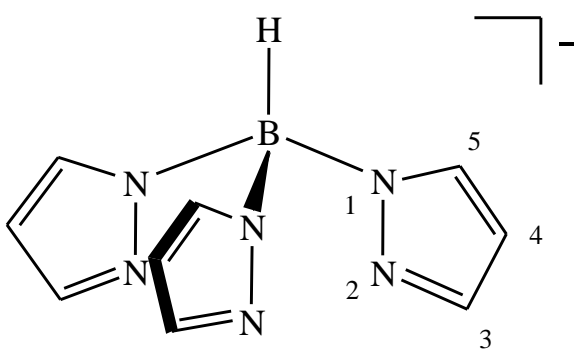

Hydrotris(1-pyrazolyl)borate (Tp)

Figure 1 
In spite of these useful features, the coordination chemistry of Tpms remains little explored. Hence, also in view of our interest on the synthesis of Tpms complexes with diverse transition metals, namely $\mathrm{V},{ }^{[26]} \mathrm{Re},{ }^{[27]} \mathrm{Fe}^{[26]}$ or $\mathrm{Cu}^{[26,28]}$, and their application in catalysis, ${ }^{[26,29,30,31]}$ and in pursuit of our long standing studies on the chemistry of molybdenum, ${ }^{[32,33]}$ we decided to investigate the unexplored Tpms-Mo coordination chemistry. The main goals of the current study are as follows: i) extend the promising coordination chemistry of Tpms to Mo; ii) investigate the structural role of the sulfonate group in the resulting complexes; iii) and compare the geometrical and electronic properties of the Tpms-Mo complexes with those of the Tp analogues.

Several Mo complexes with the neutral unfunctionalized hydrotris(1-pyrazolyl)methane Tpm $\left[\mathrm{Tpm}=\mathrm{HC}(\mathrm{pz})_{3}\right]$ and its substituted derivatives are known. ${ }^{[5,6]}$ The first one, $\left[\mathrm{Mo}(\mathrm{Tpm})(\mathrm{CO})_{3}\right]$, has been obtained from the reaction of $\left[\mathrm{Mo}(\mathrm{CO})_{6}\right]$ with $\mathrm{Tpm}^{[34]}$ and shown to be a versatile starting material. Several mononuclear and binuclear molybdenum compounds with the methyl substituted $\left[\mathrm{HC}\left(3,5-\mathrm{Me}_{2} \mathrm{pz}\right)_{3}\right]$ ligand were also reported. ${ }^{[35]}$ The oxidation of $\left[\left\{\mathrm{HC}\left(3,5-\mathrm{Me}_{2} \mathrm{pz}\right)_{3}\right\} \mathrm{Mo}(\mathrm{CO})_{3}\right]$ by various oxidants, such as $\mathrm{SOCl}_{2}, \mathrm{Br}_{2}, \mathrm{I}_{2}$, and $\mathrm{HNO}_{3}$, was described, affording mononuclear $\mathrm{Mo}^{\mathrm{III}}$ and $\mathrm{Mo}^{\mathrm{VI}}$ complexes of the type $\left[\left\{\mathrm{HC}\left(3,5-\mathrm{Me}_{2} \mathrm{pz}\right)_{3}\right\} \mathrm{MoX}_{3}\right](\mathrm{X}=\mathrm{Cl}, \mathrm{Br}, \mathrm{I}$, and $\mathrm{O}) \cdot{ }^{[35]}$ Dimolybdenum complexes possessing the thermodynamically stable $\left(\mathrm{Mo}_{2} \mathrm{O}_{4}\right)^{2+}$ core were also obtained. ${ }^{[35]}$

More recently, the syntheses of the molybdenum $(0)\left[\mathrm{Mo}(\mathrm{CO})_{3}\left(\mathrm{~L}_{3}\right)\right], \quad\left[\mathrm{Mo}(\mathrm{CO})_{4}\left(\mathrm{~L}_{2}\right)\right]$, $\left[\mathrm{Mo}(\mathrm{CO})_{3}(\mathrm{NCMe})\left(\mathrm{L}_{2}\right)\right]$ and molybdenum( $\left.\mathrm{VI}\right)\left[\mathrm{MoCl}_{2} \mathrm{O}_{2}\left(\mathrm{~L}_{2}\right)\right]$ complexes were performed with the tridentate $\left(\mathrm{L}_{3}\right)$ and bidentate $\left(\mathrm{L}_{2}\right)$ poly(pyrazolyl)methane ligands $(\mathrm{G} n$-dend $) \mathrm{OCH}_{2} \mathrm{C}(\mathrm{pz})_{3}$ $\left(\mathrm{L}_{3}\right)$ and $(\mathrm{G} n-$ dend $) \mathrm{CH}\left(3,5-\mathrm{Me}_{2} \mathrm{pz}\right)_{2} \quad\left(\mathrm{~L}_{2}\right) \quad[\mathrm{G} n$-dend $=$ poly(benzylether $)$ dendron $]^{[36]}$ Reactions of $\left[\mathrm{MoO}_{2} \mathrm{Cl}_{2}(\text { thf })_{2}\right]$ with potential mono- and bi-dentate pyrazole type ligands lead to octahedral complexes of formula $\left[\mathrm{MoO}_{2} \mathrm{Cl}_{2}\left(\mathrm{~L}_{1}\right)_{2}\right]$ and $\left[\mathrm{MoO}_{2} \mathrm{Cl}_{2}\left(\mathrm{~L}_{2}\right)\right]\left(\mathrm{L}_{1}=3,5-\mathrm{Me}_{2} \mathrm{pz} ; \mathrm{L}_{2}\right.$ $\left.=\mathrm{Me}_{2} \mathrm{C}(\mathrm{pz})_{2}\right),{ }^{[36]}$ whereas reactions of $\left[\mathrm{MoO}_{2} \mathrm{X}_{2}(\mathrm{thf})_{2}\right](\mathrm{X}=\mathrm{Cl}$ or $\mathrm{Br})$ with potential tridentate ligands, e.g. tris(pyrazolyl)methane or tris(pyrazolyl)borate, lead to the replacement of both 
co-ordinated solvent molecules and one of the halogen ligands to give $\left[\mathrm{MoO}_{2} \mathrm{X}\left(\mathrm{L}_{3}\right)\right] \mathrm{X}[\mathrm{X}=\mathrm{Cl}$ or $\left.\mathrm{Br}, \mathrm{L}_{3}=\mathrm{HC}(\mathrm{pz})_{3}, \mathrm{HC}\left(3,5-\mathrm{Me}_{2} \mathrm{pz}\right)_{3}\right] .{ }^{[36]}$ These complexes were shown to catalyse cyclooctene epoxidation with ${ }^{t} \mathrm{BuOOH} \cdot{ }^{[37]} \mathrm{In}$ addition, oxidation of $\left[\mathrm{Mo}(\mathrm{Tpm})(\mathrm{CO})_{3}\right]$ by $\mathrm{I}_{2}$ or $\mathrm{Br}_{2}$ gave rise to the seven-coordinated $\left[\mathrm{Mo}(\mathrm{Tpm}) \mathrm{X}(\mathrm{CO})_{3}\right] \mathrm{X}$ derivatives $(\mathrm{X}=\mathrm{I}$ or $\mathrm{Br})$, whereas protonation with $\mathrm{HBF}_{4}$ afforded the hydrido complex $\left[\mathrm{Mo}(\mathrm{Tpm}) \mathrm{H}(\mathrm{CO})_{3}\right]\left[\mathrm{BF}_{4}\right] .^{[38]}$ In contrast to the above described Tpm Mo derivatives, the reactivity with Mo of the related anionic sulfonate functionalized species, i.e. the tris(1-pyrazolyl)methanesulfonate (Tpms), had not yet been investigated, to our knowledge. This has encouraged us, within the above goals of the present study, to prepare the first Mo-Tpms compounds, to examine their properties and, when appropriate, to compare them with those of the neutral Tpm analogues.

\section{Results and Discussion}

\section{Synthesis and characterization of $\mathrm{Li}\left[\mathrm{Mo}(\mathrm{Tpms})(\mathrm{CO})_{3}\right]$ (1) and its conversion to $\left[\mathrm{Mo}(\mathrm{Tpms})(\mathrm{CO})_{2}(\mu-\mathrm{CO}) \operatorname{Li}\left(\text { thf }_{2}\right]_{\mathrm{n}}(2)\right.$}

Reaction of the lithium salt LiTpms $\left[\mathrm{Tpms}=\mathrm{SO}_{3} \mathrm{C}(\mathrm{pz})_{3}\right]$ with $\left[\mathrm{Mo}(\mathrm{CO})_{6}\right]$ in refluxing $\mathrm{CH}_{3} \mathrm{CN}$ afforded $\mathrm{Li}\left[\mathrm{Mo}(\mathrm{Tpms})(\mathrm{CO})_{3}\right](\mathbf{1})$, isolated in high yield as a yellowish-green powder upon concentration of the reaction solution (Scheme 1). Compound (1) is air-sensitive, in particular in solution, and is readily soluble in water $\left(S_{25^{\circ} \mathrm{C}} \approx 16 \mathrm{mg} \cdot \mathrm{mL}^{-1}\right)$ and in other polar solvents such as $\mathrm{MeOH}, \mathrm{CH}_{3} \mathrm{CN}$, thf, $\mathrm{CHCl}_{3}$ and $\mathrm{CH}_{2} \mathrm{Cl}_{2}$. The ${ }^{1} \mathrm{H}$ and ${ }^{13} \mathrm{C}$ NMR spectra of (1) in $\mathrm{CD}_{3} \mathrm{OD}$ are indicative of a $\mathrm{C}_{3 \mathrm{v}}$ symmetry, with the Tpms ligand coordinated to the Mo atom through the three equivalent pyrazolyl groups. Its solid-state infrared spectrum shows strong $v(\mathrm{CO})$ bands at 1916 and 1756 (broad) $\mathrm{cm}^{-1}$. These values are considerably lower than those for $\left[\mathrm{Mo}(\mathrm{CO})_{6}\right], 1990 \mathrm{~cm}^{-1},{ }^{[39]}$ consistent with a greater extent of Mo-CO $\pi$-backbonding in the $\left[\mathrm{Mo}(\mathrm{Tpms})(\mathrm{CO})_{3}\right]^{-}$unit than in the hexacarbonylmolybdenum compound. The Tpms ligand, in fact, replaces three stronger $\pi$-acceptor carbonyl groups in $\left[\mathrm{Mo}(\mathrm{CO})_{6}\right]$, increasing 
the metal electron density. A comparison with $\left[\mathrm{Mo}(\mathrm{Tp})(\mathrm{CO})_{3}\right]^{-}$and $\left[\mathrm{Mo}(\mathrm{Cp})(\mathrm{CO})_{3}\right]^{-}\left(\mathrm{Cp}=\eta^{5}-\right.$ $\mathrm{C}_{5} \mathrm{H}_{5}$ ), the hydrotris(1-pyrazolyl)borate and cyclopentadienyl analogues, respectively, reveals that the CO IR frequencies decrease in the order Tpms $>$ Cp $>$ Tp $\left(\right.$ e.g. 1900, 1796, $1747 \mathrm{~cm}^{-1}$ for $\left[\mathrm{Mo}(\mathrm{Cp})(\mathrm{CO})_{3}\right]^{-},{ }^{[40]}$ and $1890,1750 \mathrm{~cm}^{-1}$ for $\left.\left[\mathrm{Mo}(\mathrm{Tp})(\mathrm{CO})_{3}\right]^{-[41]}\right)$, suggesting the opposite order of the electron-donor character of those ligands, i.e. $\mathrm{Tp}>\mathrm{Cp}>\mathrm{Tpms}$.

The electrospray ionisation (ESI) MS spectrum of compound 1 in $\mathrm{CH}_{3} \mathrm{CN}$ (Figure $\mathrm{S} 1$ in Supplementary information), in the negative mode, shows a very clean isotopic pattern centred at $m / z=475$, which agrees with the theoretical isotopic distribution of [Mo(Tpms) $\left.(\mathrm{CO})_{3}\right]^{-}$. The same pattern is also observed in $\mathrm{CH}_{2} \mathrm{Cl}_{2}$.

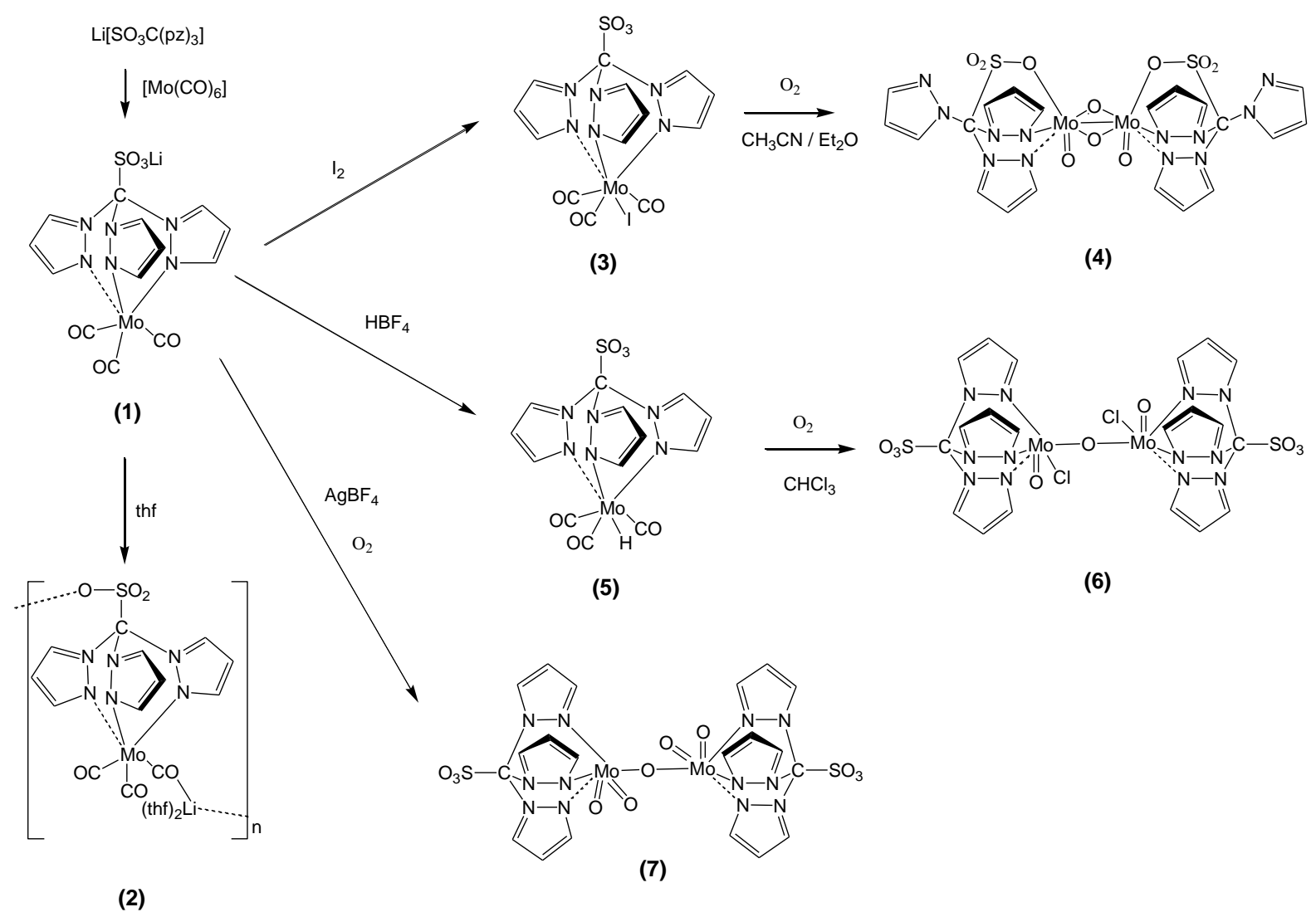

Scheme 1

Recrystallization from hot $\mathrm{CH}_{3} \mathrm{CN}$ of LiTpms afforded white crystals that were analyzed by X-ray diffraction (Figure 2). Each [Tpms] $]^{-}$unit bridges two Li cations acting as a bidentate 
N,O ligand for each of them and, on the whole, as a tetradentate $\mathrm{N}_{2} \mathrm{O}_{2}$ chelating agent. The 1D polymeric structure that is formed shows a zigzag arrangement in which three different atom chains can be outlined (Figure S2, Supplementary information): -(Li-O-S-O)-, -(Li-N-N-C-SO)- and -(Li-N-N-C-N-N)-. The metal centres present distorted tetrahedral environments, each one joining two six-membered Li-O-S-C-N-N cycles in a spirobicyclic fashion. As a consequence of the severe strain conferred by these cycles, the internal O-Li-N bond angles are considerably smaller $\left[92.2(8)-96.7(8)^{\circ}\right.$ range $]$ than the other four angles $[104.5(9)-$ 126.4(12 $)^{\mathrm{o}}$ range]. The highest values of the $\mathrm{O}-\mathrm{Li}-\mathrm{N}$ angles involve different Tpms ligands.

(a)

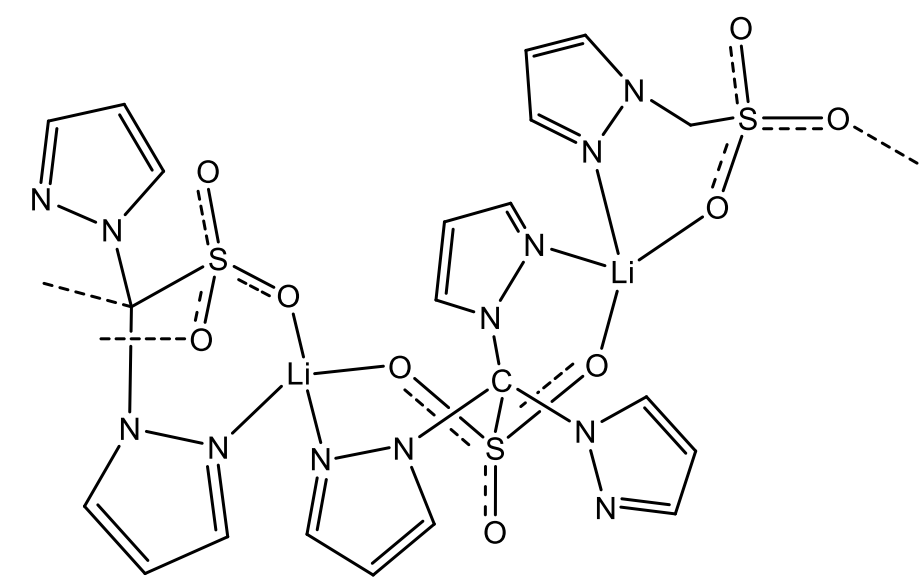

(b)

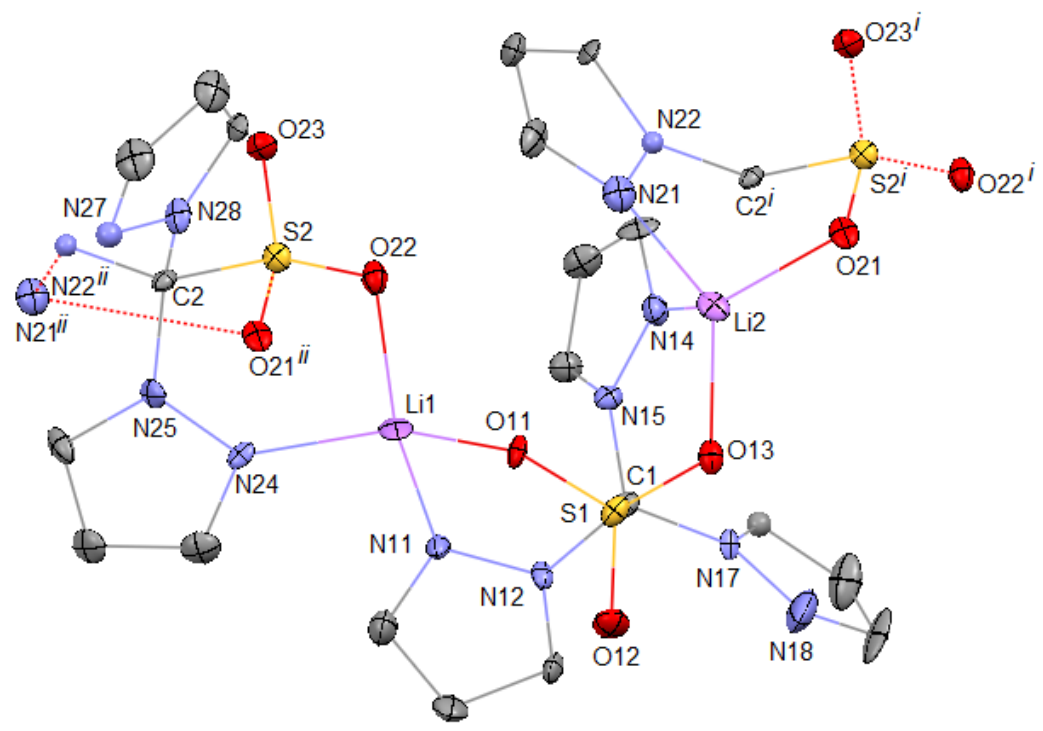

Figure 2 - (a) Fragment of [LiTpms $]_{\mathrm{n}}$ and (b) ORTEP arbitrary view with atom labelling scheme. Thermal ellipsoids are drawn at 30\% probability. All hydrogen atoms were omitted for clarity. Selected distances (̊̊): Li1-N11, 2.015(19); Li1-N24, 2.02(2); Li1-O11, 1.93(2); Li1-O22 1.94(2); Li2-N14, 2.06(2); Li2-N21 2.062(19); Li2-O13, 1.891(19); Li2-O21, 1.93(2); S1-O11, 1.455(7) ; S1O12, 1.424(12); S1-O13, 1.454(8); S2-O21, 1.444(8) ; S2-O22, 1.455(8) ; S2-O23, 1.449(12). 
Selected angles $\left({ }^{\circ}\right)$ : O11-Li1-O22, 112.3(11); N11-Li1-N24, 107.1(10); O11-Li1-N11, 94.6(9); O22Li1-N24, 94.9(9); O22-Li1-N11, 126.4(12); O11-Li1-N24, 124.4(12); O13-Li2-O21, 116.2(11); N21Li2-N14, 104.5(9); O13-Li2-N14, 96.7(8); O21-Li2-N21, 92.2(8); O13-Li2-N21, 126.0(9); O21-Li2$\mathrm{N} 14,123.5(9)$. Symmetry codes to generate equivalent atoms: i) x,1+y,z; ii) x,-1+y,z.

Upon recrystallization of (1) from thf/Et $\mathrm{Et}_{2} \mathrm{O}$ at $0^{\circ} \mathrm{C}$, green crystals of the new compound $\left[\mathrm{Mo}(\mathrm{Tpms})(\mathrm{CO})_{2}(\mu-\mathrm{CO}) \operatorname{Li}(\mathrm{thf})_{2}\right]_{\mathrm{n}}$ (2) were obtained and analysed by X-ray diffraction (Figure 3, Scheme 1). Compound $\mathbf{2}$ is a 1D-type coordination polymer in which the $\left[\mathrm{Mo}(\mathrm{Tpms})(\mathrm{CO})_{3}\right]^{-}$moiety acts as a building block, leading to an asymmetric unit containing one Mo centre and one $\mathrm{Li}(\mathrm{thf})_{2}$ moiety bound to the $\mathrm{O} 12$ atom of the sulfonyl group and to the $\mathrm{O} 3$ atom of a bridging $\mathrm{CO}$ (Figure 3). The Tpms group acts as a bridging tetradentate ligand in the $\mathrm{N}, \mathrm{N}, \mathrm{N}, \mathrm{O}\left(\kappa^{4}: N, N, N, O\right)$ coordination mode, bound to the Mo atom through the pyrazolyl nitrogens $\mathrm{N} 11, \mathrm{~N} 14$ and N17, and to the Li atom through the O12 oxygen. The N-Mo-N angles are restrained by this chelating ligand and range from $77.29(16)$ to $77.79(16)^{\mathbf{o}}$; the wider C-Mo-X ( $\mathrm{X}=\mathrm{C}$ or $\mathrm{N})$ angle ranges from $86.3(2)$ to $175.0(2)^{\circ}$, therefore leading to a highly distorted octahedron around the Mo atom. The Mo-N-N-C torsion angles of the pyrazolyl rings display values from 174.90 to $177.75^{\circ}$ thus revealing a low degree of tilting of the rings. The $\mathrm{O}_{4}$ environment around the $\mathrm{Li}^{+}$cation shapes an almost regular tetrahedron $(\mathrm{O}-$ Li-O angles in the 108.1(5) - 114.4(5) ${ }^{\mathrm{o}}$ range). The solid state structure of compound 2 also exhibits the presence of intermolecular $\mathrm{C}-\mathrm{H}---\pi$ interactions (Figure S2, in Supplementary Information) between the thf $\mathrm{C}(202)-\mathrm{H}(20 \mathrm{D})$ and the N17-N18 pirazolyl ring (H $\cdots$ centroid distance of $2.777 \AA$ with a C-H $\cdots$ centroid angle of $145.23^{\circ}$ ), as well as (although considerably

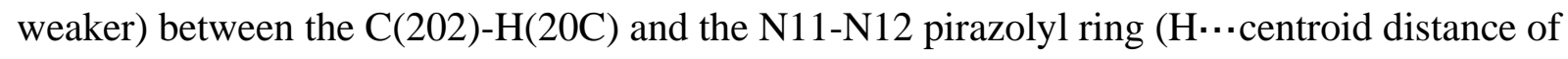
$3.061 \AA$ with a $\mathrm{C}-\mathrm{H} \cdots$ centroid angle of $139.34^{\circ}$ ). These interactions, together with several hydrogen bonds involving all the oxygen atoms, help to stabilise the structure in the solid state. Structure 2 can be qualified as a heterometallic supramolecular chain. The nearest distance between two Mo atoms or two Li atoms in a chain is $10.794 \AA$, the same as the unit 
cell parameter $b$. The shortest interchain $\mathrm{Mo} \cdots \mathrm{Mo}, \mathrm{Li} \cdots \mathrm{Li}$ and $\mathrm{Mo} \cdots \mathrm{Li}$ distances are of 7.196, 9.734 and $7.462 \AA$, respectively. These distances considerably exceed the sum of the van der Waals radii of two Mo or two Li atoms and hence the chains are effectively separated, as shown in Figures S3 and S4 (Supplementary information).

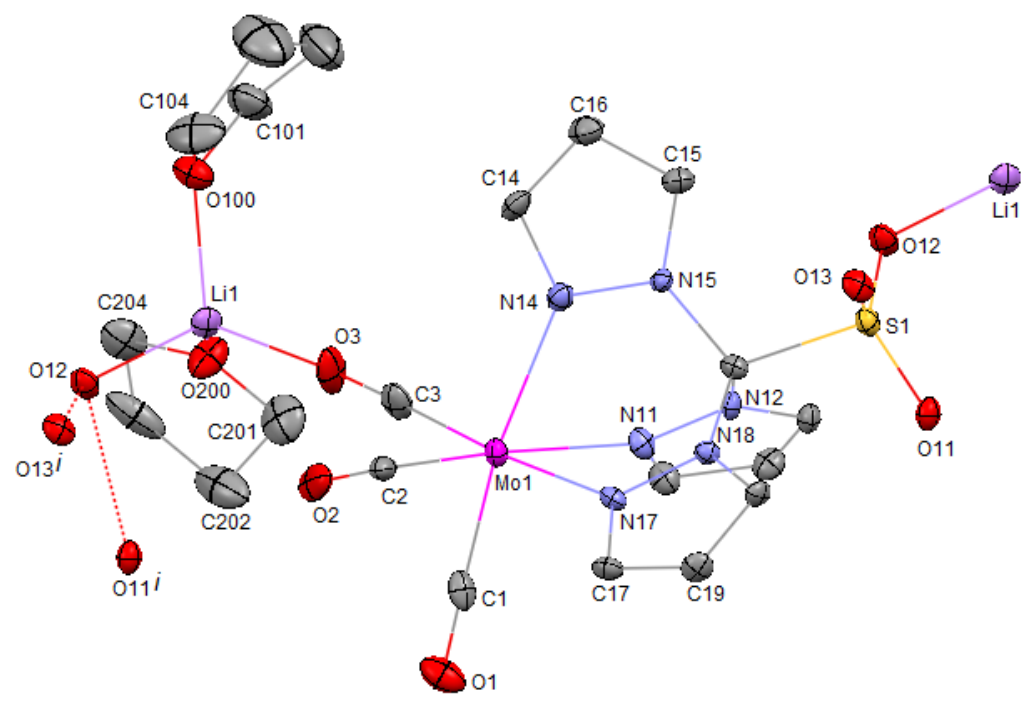

Figure 3. ORTEP view of the asymmetric unit of $\left[\mathrm{Mo}(\mathrm{Tpms})(\mathrm{CO})_{2}(\mu-\mathrm{CO}) \mathrm{Li}(\text { thf })_{2}\right]_{\mathrm{n}}(2)$ with atom labelling scheme. Thermal ellipsoids are drawn at 30\% probability. All hydrogen atoms were omitted for clarity. Selected distances (̊̊): Mo1-N11, 2.226(4) ; Mo1-N14, 2.245(5) ; Mo1-N17, 2.232(4) ; Mo1-C1, 1.922(7) ; Mo1-C2, 1.911(6) ; C1-O1, 1.174(7) ; C2-O2, 1.159(6) ; C3-O3, 1.194(7) ; O3Li1, 1.898(10) ; O12- Li1 ${ }^{i}$ 1.933(10) ; Li1-O100, 1.929(10); Li1-O200 1.894(11); S1-O11, 1.432(4); S1-O12, 1.451(4) ; S1-O13, 1.433(4). Selected angles $\left(^{\circ}\right)$ : N11-Mo1- N14, 77.29(16); N11-Mo1-N17, 77.47(16) ; N17-Mo1-N14, 77.79(16) ; C3-Mo1-N17, 175.0(2) ; C3-Mo1-C2 ; 86.5(2) ; O1-C1-Mo1, 178.8(5); O2-C2-Mo1, 177.1(5); O3-C3-Mo1, 177.0(5); C3-O3-Li, 164.9(5). Symmetry codes to generate equivalent atoms: (i) $\mathrm{x},-1+\mathrm{y}, \mathrm{z}$.

\section{Reactions of $\operatorname{Li}\left[\mathrm{Mo}(\mathrm{Tpms})(\mathrm{CO})_{3}\right](1)$}

\section{A) With $\mathbf{I}_{2}$}

The controlled oxidation of complex (1) with 1 equiv. of iodine gave a reddish-brown product formulated as $\left[\mathrm{Mo}(\mathrm{Tpms}) \mathrm{I}(\mathrm{CO})_{3}\right]$ (3) on the basis of $\mathrm{IR},{ }^{1} \mathrm{H} \quad \mathrm{NMR}$ and ${ }^{13} \mathrm{C} \mathrm{NMR}$ spectroscopies. Complex $\mathbf{3}$ is diamagnetic, air sensitive and readily soluble in chlorinated 
hydrocarbons, $\mathrm{CH}_{3} \mathrm{CN}$, thf and also in water $\left(S_{25^{\circ} \mathrm{C}} \approx 5 \mathrm{mg} \cdot \mathrm{mL}^{-1}\right)$, not considerably soluble in alcohols, diethyl ether and hydrocarbon solvents. In accordance with a $\mathrm{C}_{\mathrm{s}}$ symmetry, the infrared spectrum of $(\mathbf{3})$ in the solid state shows three carbonyl stretching bands $\left(2 \mathrm{~A}^{\prime}+\mathrm{A}^{\prime \prime}\right)$ at 2039, 1966 and $1944 \mathrm{~cm}^{-1}$. They are shifted to higher frequencies compared with those of the starting $\mathrm{Mo}^{0}$ tricarbonyl complex, reflecting the decrease in electron density at the central metal atom as a result of the oxidation. This pattern is consistent with either a 4:3 "piano stool" structure ${ }^{[38,41]}$ or a 3:3:1 structure with axial $\mathrm{CO}^{[39]}$ (Scheme 2 a) and b), respectively). Both these possibilities have already been reported for related complexes, such as $\left[\mathrm{Mo}(\mathrm{Tp}) \operatorname{Br}(\mathrm{CO})_{3}\right]^{[41]}$ and $\left[\mathrm{Mo}(\mathrm{Tpm}) \operatorname{Br}(\mathrm{CO})_{3}\right]^{[38]}(4: 3 \quad$ “piano stool” structure $)$ or $\left[\mathrm{Mo}\left(\mathrm{Tp}^{i \mathrm{Pr}}\right) \mathrm{I}(\mathrm{CO})_{3}\right]^{[42]}$ (3:3:1 carbonyl capped octahedral structure). The 3:3:1 structure with the halide in the axial position [Scheme $2 \mathrm{c}$ )] has never been observed and is excluded by the IR study because its $C_{3 v}$ symmetry would require only two normal stretching modes $\left(A_{1}+E\right)$ for the carbonyl groups.

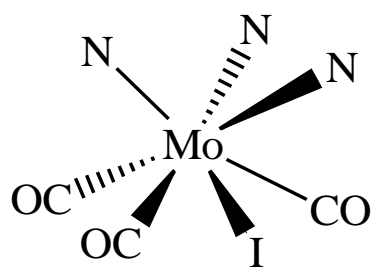

a)

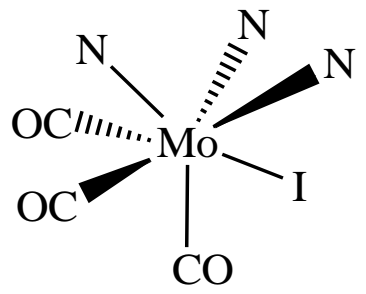

b)

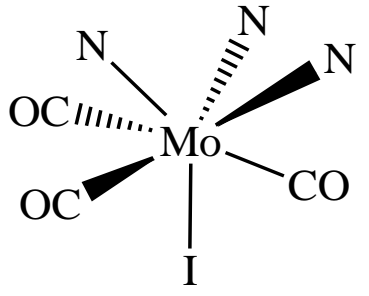

c)

Scheme 2. Possible isomers for the 7-coordinated complex 3: a) 4:3 "piano stool" structure ( $\mathrm{C}_{\mathrm{s}}$ symmetry); b) 3:3:1 structure with $\mathrm{CO}$ in the axial position ( $\mathrm{C}_{\mathrm{s}}$ symmetry); c) 3:3:1 structure with $\mathrm{I}$ in the axial position $\left(\mathrm{C}_{3 \mathrm{v}}\right.$ symmetry).

A comparison with the hydrotris(1-pyrazolyl)borate analogue $\left[\mathrm{Mo}(\mathrm{Tp}) \mathrm{I}(\mathrm{CO})_{3}\right]$ reveals that the Tpms complex exhibits $v(C O)$ frequencies higher than those of the latter compound (2016, $\left.1950,1910 \mathrm{~cm}^{-1}\right),{ }^{[41]}$ also in accordance with the lower electron-donor character of Tpms relative to $\mathrm{Tp}$. 
The ${ }^{1} \mathrm{H}$ NMR analysis of complex (3) shows one set of equivalent pyrazolyl rings, therefore indicating a fluxional process on the NMR time scale. The fluxionality of 7-coordinated molybdenum(II) and tungsten(II) complexes is well known. ${ }^{[38,41,42,43]}$

Slow diffusion of $\mathrm{Et}_{2} \mathrm{O}$ into a saturated $\mathrm{CH}_{3} \mathrm{CN}$ solution of complex (3) afforded reddishbrown crystals suitable for X-ray diffraction study. The data revealed the tetraoxo $\mathrm{Mo}^{\mathrm{V}}$ dimer $[\mathrm{Mo}(\mathrm{Tpms}) \mathrm{O}(\mu-\mathrm{O})]_{2} 4$ (Scheme 1 and Figure 4) which crystallized with two molecules of $\mathrm{CH}_{3} \mathrm{CN}$. Compound (4) derived from the slow oxidation of (3) with air, as a consequence of $\mathrm{O}_{2}$ diffusion during the crystallization procedure.

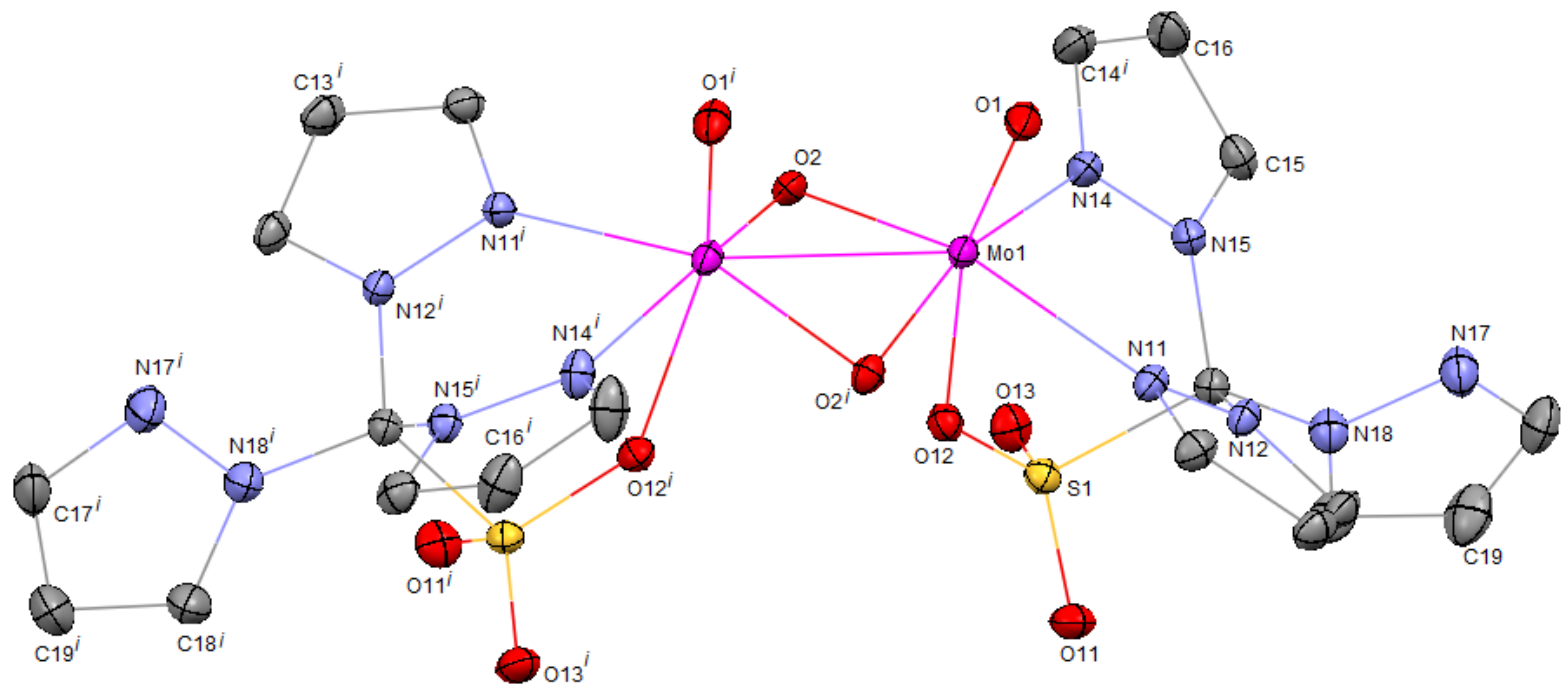

Figure 4. An ORTEP view of compound $[\mathrm{Mo}(\mathrm{Tpms}) \mathrm{O}(\mu-\mathrm{O})]_{2} \cdot 2 \mathrm{CH}_{3} \mathrm{CN} \quad\left(4.2 \mathrm{CH}_{3} \mathrm{CN}\right)$. The $\mathrm{CH}_{3} \mathrm{CN}$ molecules and the hydrogen atoms are omitted for clarity. Selected distances ( $\mathrm{A})$ : Mo1-N11, 2.189(2); Mo1-N14, 2.211(2); Mo1-O1, 1.673(2); Mo1 ${ }^{i} \mathrm{O} 2$, 1.9345(18); Mo1-O2, 1.940(2); Mo1-O12, 2.303(2); Mo1-Mo1 ${ }^{i}$, 2.5545(4); S1-O11, 1.435(2); S1-O12, 1.472(2); S1-O13, 1.438(2). Selected angles $\left({ }^{\circ}\right)$ : N11-Mo1- N14, 82.47(9); O12-Mo1-N14, 75.80(8); O1-Mo1-O12, 162.95(9); Mo1-O2$\mathrm{Mo1}^{i}$, 82.50(7); O2-Mo1-O2, 94.25(8); O2-Mo1-Mo1 ${ }^{i}$, 48.66(5). Symmetry code to generate equivalent atoms $i: 1-\mathrm{x}, \mathrm{y}, 3 / 2-\mathrm{z}$. 
The asymmetric unit of $\mathbf{4}$ comprises half of the complex molecule and one $\mathrm{CH}_{3} \mathrm{CN}$ molecule. The binuclear complex contains a crystallographically imposed twofold axis which passes through the centre of the Mo1-Mo1 ${ }^{i}$ bond, perpendicularly to the central $\mathrm{Mo}_{2} \mathrm{O}_{2}$ plane. The molecular geometry is that of a typical edge-sharing bioctahedron, with two terminal oxo ligands placed on the same side (syn) of the $\mathrm{Mo}_{2} \mathrm{O}_{2}$ place, and two bridging $\mathrm{O}$-atoms, displaying the well-known $\left(\mathrm{Mo}_{2} \mathrm{O}_{4}\right)^{2+}$ bridging structure found in many compounds. ${ }^{[44-48]}$ The anionic Tpms group acts as a tridentate N,N,O ligand. The basal positions in each octahedron are occupied by the N11 and N14 atoms and the bridging O2 oxygen atoms and the two distorted octahedra share the common $\mathrm{O} 2-\mathrm{O} 2^{i}$ edge; the apical positions are taken up by the oxido $\mathrm{O} 1$ and $\mathrm{O} 12$ atoms from the sulfonate group. Due to the sulfonate coordination, the S1O12 bond length of $1.472(2) \AA$ is slightly longer than the other two S1-O distances $(1.435(2)$ and 1.438(2) $\AA$ ). The Mo-Mo distance is $2.5545(4) \AA$, similar to that in related $\mathrm{Mo}^{\mathrm{V}}$ dinuclear compounds, ${ }^{[46,48,49]}$ and is consistent with a metal-metal single bond. The disparity in the terminal and bridging molybdenum-oxygen distances (Figure 4) is also found in other $\mathrm{Mo}_{2} \mathrm{O}_{4}$ structures. ${ }^{[49]}$ The O2-Mo1-N14 ${ }^{i}\left[163.61(9)^{\circ}\right]$ and O2-Mo1-N11 ${ }^{i}\left[156.12(9)^{\circ}\right]$ angles in the equatorial plane, together with the O12-Mo1-O1 $\left[162.95(9)^{\circ}\right]$ angle in the axial plane, are rather compressed and force the Mo1 and the bridging $\mathrm{O} 2$ oxygen atoms to shift away, in opposite directions, from the least-square basal plane. As a consequence, the Mo-O2-Mo ${ }^{i}$ and the Mo-O $2^{i}-\mathrm{Mo}^{i}$ planes make an angle of $25.83^{\circ}$. A similar folding has already been reported for other related structures $\left[149^{\circ}\right.$ in $\left[\mathrm{Mo}\left(\mathrm{Cp}^{*}\right) \mathrm{O}_{2}\right]_{2}\left(\mathrm{Cp}^{*}=\eta^{5}-\mathrm{C}_{5} \mathrm{Me}_{5}\right)^{[50]}$ and $152^{\circ}$ in $\left.\left[\mathrm{Mo}(\mathrm{Cp}) \mathrm{O}_{2}\right]_{2}{ }^{[51]}\right]$ and was shown to allow the formation of the Mo-Mo bond without excessively distorting the Mo-O-Mo angles in the bridge, which usually take values very close to the $82.50(7)^{\circ}$ angle found in our case $\left(83.3^{\circ}\right.$ in $\left[\mathrm{Mo}\left(\mathrm{Cp}^{*}\right) \mathrm{O}_{2}\right]_{2}{ }^{[50]}$ and $84.2^{\circ}$ in $\left.\left[\mathrm{Mo}(\mathrm{Cp}) \mathrm{O}_{2}\right]_{2}^{[51]}\right)$

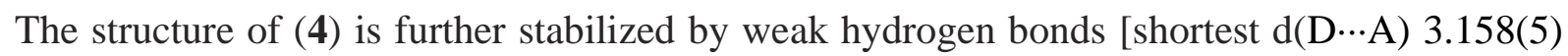
$\AA$; shortest $\angle$ (DHA) $133.00^{\circ}$ ] involving the non coordinated $\mathrm{O} 11$ atom of the sulfonate group 
which simultaneously interacts with one of the pyrazolyl groups of a vicinal dimer and with the methyl group of a $\mathrm{CH}_{3} \mathrm{CN}$ molecule whose nitrogen atom, in turn, interacts with a pyrazolyl ring of a third molecule. No specific $\pi \cdots \pi$ stacking interactions are identifiable between the pyrazolyl rings, the shortest interaction between the N14 containing pyrazolyl rings of neighbouring molecules being of $4.360 \AA$.

\section{B) With $\mathrm{HBF}_{4}$}

Complex $\mathbf{1}$ is readily protonated with $\mathrm{HBF}_{4}$ in dry acetonitrile to give the hydrido species [Mo $\left.(\mathrm{Tpms}) \mathrm{H}(\mathrm{CO})_{3}\right](\mathbf{5})$ which was isolated in good yield as a green powder. The compound is significantly air-sensitive as a solid and highly sensitive in solution, turning immediately to black in the presence of $\mathrm{O}_{2}$. It is sparingly soluble in water $\left(S_{25^{\circ} \mathrm{C}} \approx 1 \mathrm{mg} \cdot \mathrm{mL}^{-1}\right)$. The three carbonyl stretching absorptions in the solid state IR spectrum $\left(2025,1945\right.$ and $\left.1912 \mathrm{~cm}^{-1}\right)$ are indicative of a $\mathrm{C}_{\mathrm{s}}$ 7-coordinated structure, as observed for the previously described complex (3) and other related hydride complexes involving a facially coordinating ligand. ${ }^{[41,52-54]}$ The lower $v(\mathrm{CO})$ values of $(\mathbf{5})$ as compared to those of $(\mathbf{3})$ reflect the stronger electronegativity of iodide relative to hydride and therefore the higher metal electron density in the latter, as observed for similar systems. ${ }^{[38,41,52,55]}$ In contrast, 5 displays higher $v(\mathrm{CO})$ values than the Tp analogue $\left[\mathrm{Mo}(\mathrm{Tp}) \mathrm{H}(\mathrm{CO})_{3}\right]\left(2000,1906,1887 \mathrm{~cm}^{-1}\right.$, in THF $),{ }^{[41]}$ consistent with the weaker electron-donor ability of Tpms in comparison with Tp (see above). The ${ }^{1} \mathrm{H}$ NMR spectrum $\left(\mathrm{CDCl}_{3}\right)$ exhibits one set of equivalent pyrazolyl rings, suggesting a fluxional behaviour. The chemical shift for the hydridic proton $(-3.23 \mathrm{ppm})$ is similar to those reported for $\left[\mathrm{Mo}(\mathrm{Tpm}) \mathrm{H}(\mathrm{CO})_{3}\right]\left[\mathrm{BF}_{4}\right](\delta-3.12)^{[38]}$ and analogous Tp compounds. ${ }^{[41,52-54]}$

By slow evaporation of a chloroform solution of $\mathbf{5}$, reddish-brown crystals were obtained. The X-ray diffraction analysis disclosed the structure of the oxidized $[\mathrm{Mo}(\mathrm{Tpms}) \mathrm{OCl}]_{2}(\mu-\mathrm{O})$ complex 6 (Scheme 1) which crystallized with 6 chloroform molecules. An ORTEP drawing of complex (6) is shown in Figure 5. Due to the rather poor quality of this structure, only a 
restricted discussion is presented. The asymmetric unit contains half of the molecule, with the bridging $\mathrm{O} 2$ atom sitting on an inversion centre, which imposes a perfect linearity to the MoO-Mo group. The molecule includes two terminal oxygen atoms, displaying the well-known $\left(\mathrm{Mo}_{2} \mathrm{O}_{3}\right)^{4+}$ moiety. Each $\mathrm{Mo}^{\mathrm{V}}$ centre adopts a pseudo-octahedral coordination geometry with the anionic tridentate Tpms ligand bonding facially the metal atom. A similar structure containing the related hydrotris(1-pyrazolyl)borate ligand has been previously described. ${ }^{[56]}$

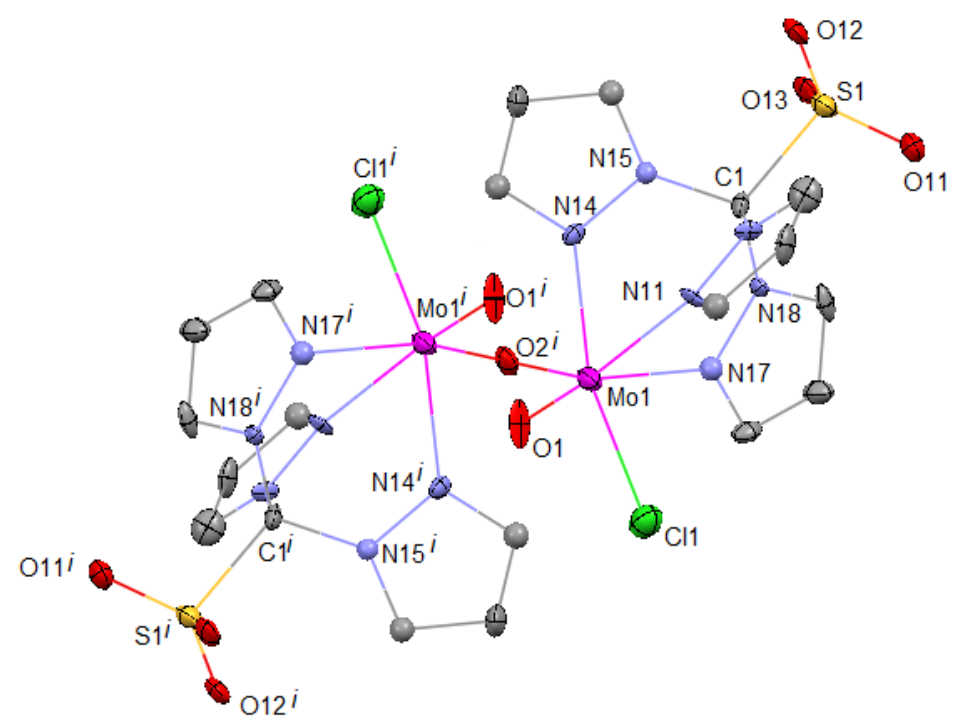

Figure 5. An ORTEP view of $[\mathrm{Mo}(\mathrm{Tpms}) \mathrm{OCl}]_{2}(\mu-\mathrm{O}) \cdot 6 \mathrm{CHCl}_{3}\left(6.6 \mathrm{CHCl}_{3}\right)$. The ellipsoids are drawn as $30 \%$ probability; the chloroform molecules and hydrogen atoms are omitted for clarity. Symmetry code to generate equivalent atoms: (i) 1-x,2-y,z.

\section{C) With $\mathrm{AgBF}_{4}$}

Reaction of compound 1 with 1 equiv. of $\mathrm{AgBF}_{4}$ in thf gave a reddish-brown powder which, upon attempted crystallization by slow diffusion of $\mathrm{Et}_{2} \mathrm{O}$ into a thf solution afforded yellow crystals of a product (7) suitable for X-ray diffraction analysis. Compound $\mathbf{7}$ is the oxo-Mo ${ }^{\mathrm{VI}}$ complex $\left[\mathrm{Mo}(\mathrm{Tpms}) \mathrm{O}_{2}\right]_{2}(\mu-\mathrm{O})$ which crystallized with one molecule of thf. The two anionic tris(1-pyrazolyl)methanesulfonate groups in the molecule (Figure 6) act as $\kappa^{3}: N, N, N$ ligands, bonding facially the $\mathrm{Mo}^{\mathrm{VI}}$ centres which display the well-known $\left(\mathrm{Mo}_{2} \mathrm{O}_{5}\right)^{2+}$ bridging structure found in many related cyclopentadienyl containing compounds. ${ }^{[57-60]}$ Each molybdenum atom 
bears two terminal oxo-ligands and displays a pseudo-octahedral geometry, with the two heavily distorted octahedron sharing the $\mathrm{O} 2$ atom as common vertices. Such a distortion may be a consequence of the large intramolecular repulsion between each pair of oxo-ligands (O1Mo1-O3 and O4-Mo2-O6 angles of $104.47(16)^{\circ}$ and $104.87(15)^{\circ}$, respectively). The deviation of the Mo1-O2-Mo1 angle $\left[176.14(16)^{\circ}\right]$ from linearity can be ascribed to packing forces in the crystal, as it has already been recognized in other cases. ${ }^{[57,58]}$ The $\mathrm{Mo}=\mathrm{O}$ and Mo-O-Mo bond distances (in the 1.689(3)-1.694(3) $\AA$ and 1.879(3)-1.884(3) $\AA$ ranges, respectively) agree with their double and single bond character, respectively. The structure is stabilized by intramolecular $\pi-\pi$ stacking contacts. The N17-N18 and the N21-N22 pirazole rings are mutually involved in a face-to-face interaction with a distance of $3.627 \AA$ between the ring centroids, the H17 hydrogen atom of the former ring being directed towards the N24-N25 pyrazolyl $\pi$ cloud, and the $\mathrm{H} 21$ atom of the latter being directed towards the N14-N15

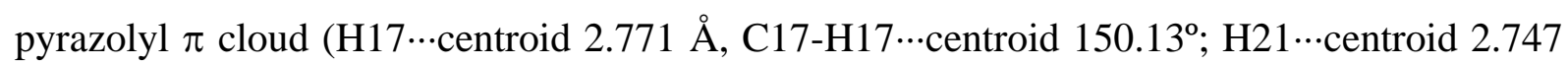

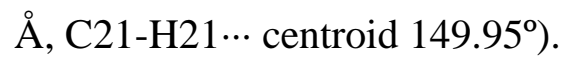

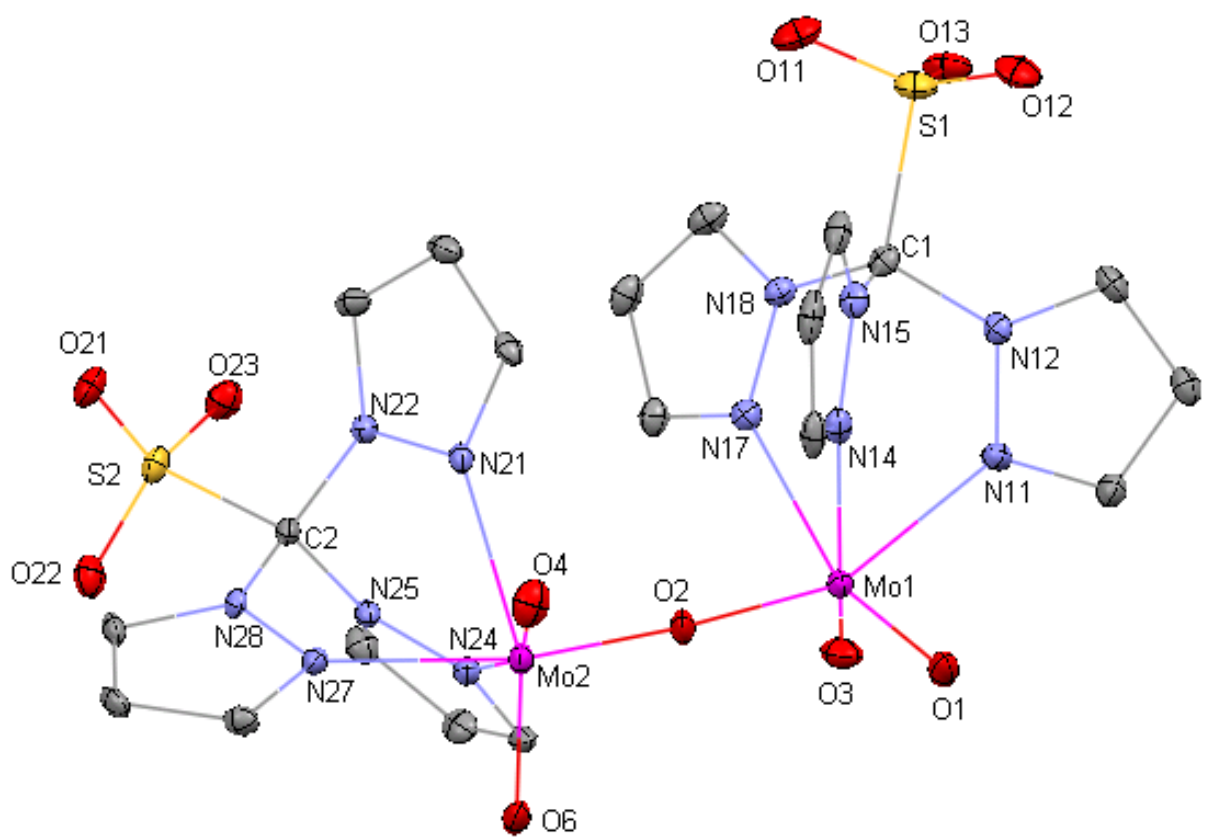

Figure 6 - An ORTEP view of $\left[\mathrm{Mo}(\mathrm{Tpms}) \mathrm{O}_{2}\right]_{2}(\mu-\mathrm{O}) \cdot$ thf $(7 \cdot$ thf $)$. The ellipsoids are drawn as $30 \%$ probability; the thf molecule and hydrogen atoms are omitted for clarity. Selected distances $(\AA)$ : Mo1N11, 2.214(3); Mo1-N14, 2.302(3); Mo1-N17, 2.308(3); Mo1-O1, 1.690(3); Mo1-O2, 1.879(3); Mo1- 
O3, 1.689(3); Mo2-N21, 2.312(3); Mo2-N24, 2.255(3); Mo2-N27, 2.194(3); Mo2-O2, 1.884(3); Mo2O4, 1.692(3); Mo2-O6, 1.694(3); S1-O11, 1.438(3); S1-O12, 1.435(3); S1-O13, 1.436(3). Selected angles $\left({ }^{\circ}\right)$ : N11-Mo1-N14, 74.20(12); N11-Mo1-N17, 74.66(11); N14-Mo1-N17, 74.78(11); O1-Mo1O3, 104.47(16); N21-Mo2-N24, 74.31(11); N21-Mo2-N27, 74.70(11); N24-Mo2-N77, 75.82(12); O4Mo1-O6, 104.87(15); Mo1-O2-Mo2, 176.14(16)

\section{Electrochemical behaviour}

Complexes $\operatorname{Li}\left[\mathrm{Mo}(\mathrm{Tpms})(\mathrm{CO})_{3}\right](\mathbf{1}),\left[\mathrm{Mo}(\mathrm{Tpms}) \mathrm{I}(\mathrm{CO})_{3}\right](\mathbf{3})$ and $\left[\mathrm{Mo}(\mathrm{Tpms}) \mathrm{H}(\mathrm{CO})_{3}\right]$ (5) exhibit, by cyclic voltammetry (at $200 \mathrm{mVs}^{-1}$ ) at a platinum electrode and in $0.2 \mathrm{M}$ $\left[{ }^{n} \mathrm{Bu}_{4} \mathrm{~N}\right]\left[\mathrm{BF}_{4}\right] / \mathrm{CH}_{2} \mathrm{Cl}_{2}$ solutions (Figure 7 , for $\mathbf{1}$ ), a single-electron reversible (for 1) or irreversible (for 3 and 5) oxidation wave (wave I) at ${ }^{\mathrm{I}} E_{1 / 2}{ }^{\mathrm{ox}}=-0.35(\mathbf{1}),{ }^{\mathrm{I}} E_{\mathrm{p}}{ }^{\mathrm{ox}}=-0.09(\mathbf{3})$ and $0.44(\mathbf{5}) \mathrm{V} v$ s. ferrocene/ferrocinium redox pair $\left(\mathrm{Fc} / \mathrm{Fc}^{+}\right)$, assigned to the $\mathrm{Mo}^{0} \rightarrow \mathrm{Mo}^{\mathrm{I}}(\mathbf{1})$ or to the $\mathrm{Mo}^{\mathrm{II}} \rightarrow \mathrm{Mo}^{\mathrm{III}}$ (3 and 5) oxidation processes. It is followed, at a higher potential, by a second reversible (for $\mathbf{3}$ ) or irreversible (for $\mathbf{1}$ and $\mathbf{5}$ ) anodic wave (wave II) at 0.60 (1), 0.18 (3) or $0.51(5) \mathrm{V} v s . \mathrm{Fc} / \mathrm{Fc}^{+}$, respectively.

In complex 1, the second oxidation process is assigned to the further oxidation yielding the 16-electron $\left[\mathrm{Mo}(\mathrm{Tpms})(\mathrm{CO})_{3}\right]^{+}$complex of $\mathrm{Mo}^{\mathrm{II}}$, its irreversibility being probably associated to fast coordination of a solvent molecule, yielding an electronically saturated product. The irreversibility of the first oxidation wave of compounds (3) and (5) signals the instability of the resulting cationic $\mathrm{Mo}^{\mathrm{III}}$ complexes, which then rapidly decompose with probable $\mathrm{CO}$ loss ${ }^{[61]}$ and, for the hydride compound (5), by deprotonation. ${ }^{[2--65]}$ 


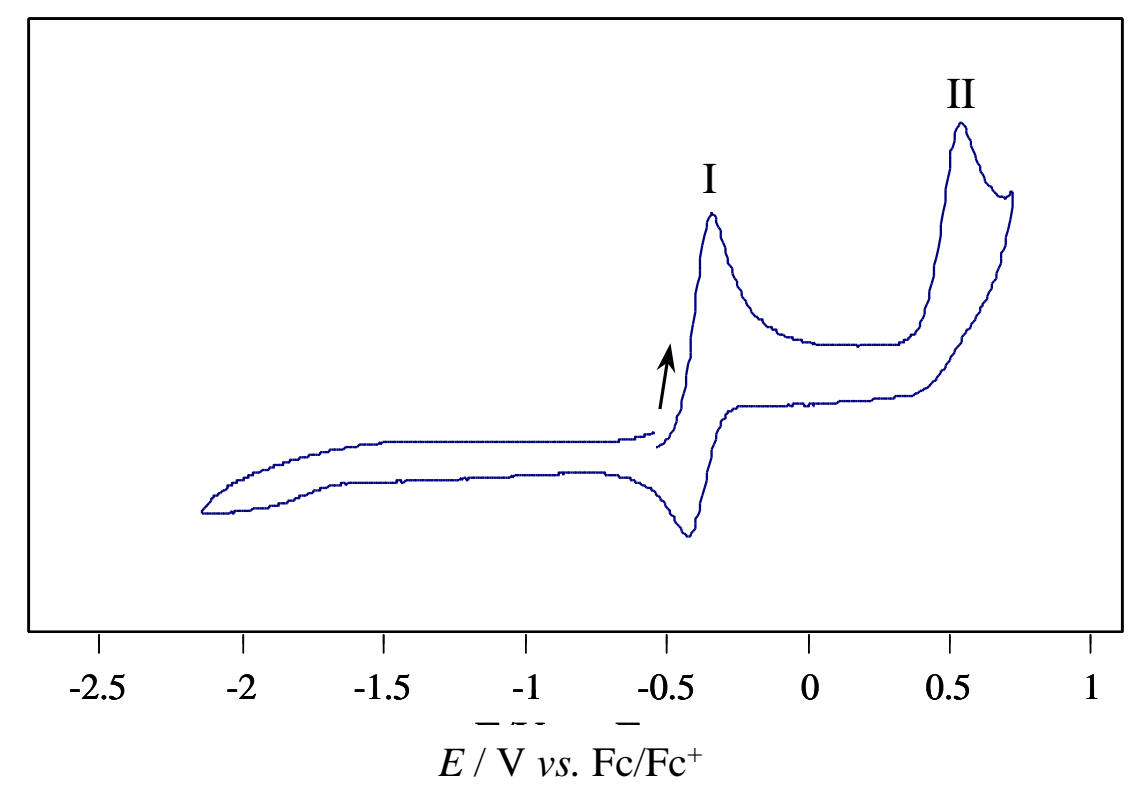

Figure 7. Cyclic voltammogram of $\mathrm{Li}\left[\mathrm{Mo}(\mathrm{Tpms})(\mathrm{CO})_{3}\right] \mathbf{1}(1.6 \mathrm{mM})$ (initial anodic scan), at a Pt electrode, in $0.2 \mathrm{M}\left[{ }^{n} \mathrm{Bu}_{4} \mathrm{~N}\right]\left[\mathrm{BF}_{4}\right] / \mathrm{CH}_{2} \mathrm{Cl}_{2}$ solution $(\mathrm{v}=200 \mathrm{mV} / \mathrm{s})$.

The first oxidation potentials of all these tricarbonyl complexes are much lower than that $\left(0.98 \mathrm{~V}\right.$ vs. $\left.\mathrm{Fc} / \mathrm{Fc}^{+}\right)$of the parent hexacarbonyl compound, on account of the replacement of three carbonyls in the latter by other more electron-donating ligands. ${ }^{[66-69]}$ The lower first oxidation potential of $\mathbf{5}$ in comparison with $\mathbf{3}$ reflects the stronger electron-donor character of the hydride relatively to the iodide ligand. ${ }^{[68]}$

The first oxidation potential of the $\mathrm{Mo}^{0}$ complex (1) $\left(-0.35 \mathrm{~V} v s . \mathrm{Fc} / \mathrm{Fc}^{+}\right)$is comparable to those (in the -0.53 to $-0.23 \mathrm{~V}$ vs. $\mathrm{Fc} / \mathrm{Fc}^{+}$range) reported for analogous molybdenum complexes of the type $\left[\mathrm{LMo}(\mathrm{CO})_{3}\right]^{\mathrm{n}}$, where $\mathrm{L}$ is a tridentate $\mathrm{N}$-donor ligand $\left[\mathrm{Tp}(\mathrm{n}=-1),{ }^{[70]}\right.$ $\mathrm{Tpm}^{\mathrm{Me}}(\mathrm{n}=0),{ }^{[71]}$ 1,4,7-trimethyl-1,4,7-triazacyclononane $(\mathrm{n}=0),{ }^{[72]}$ or 1,4,7-tribenzyl-1,4,7triazacyclononane $(\mathrm{n}=0)],{ }^{[70]}$ reflecting ${ }^{[66-68,73-75]}$ the relative donor/acceptor abilities of these different $\mathrm{L}$ ligands. The more negative value $\left(-0.53 \mathrm{~V} v s . \mathrm{Fc} / \mathrm{Fc}^{+}\right)$is reported ${ }^{[70]}$ for complex $\left[\mathrm{Mo}(\mathrm{Tp})(\mathrm{CO})_{3}\right]^{-}$and the less negative one $\left(-0.234 \mathrm{~V}\right.$ vs. $\left.\mathrm{Fc} / \mathrm{Fc}^{+}\right)$for $\left[\mathrm{Mo}\left(\mathrm{Tpm}^{\mathrm{Me}}\right)(\mathrm{CO})_{3}\right],{ }^{[71]}$ while that of $\mathbf{1}$ is intermediate, in accord with the order of the net electron-donor ability of the corresponding tripodal ligands. This is shown by the values of the electrochemical Lever $E_{\mathrm{L}}$ 
parameter (the lower this value, the stronger is the ligand electron-donor character) that parallel the above $E_{1 / 2}{ }^{\text {ox }}$ values of the complexes: $E_{\mathrm{L}}=-0.23 \mathrm{~V}(\mathrm{Tp}),{ }^{[76]}-0.09 \mathrm{~V}(\mathrm{Tpms})^{[27]}$ and $0.14 \mathrm{~V}(\mathrm{Tpm}) \cdot{ }^{[77]}$

In addition, the hydride complex $\left[\mathrm{Mo}(\mathrm{Tpms}) \mathrm{H}(\mathrm{CO})_{3}\right] \mathbf{5}$ is oxidized at a higher potential $(-0.44$ V) relative to the following related hydride compounds, in the order: $\left[\mathrm{Mo}(\mathrm{Cp}) \mathrm{H}(\mathrm{CO})_{3}\right](-0.50$ $\mathrm{V})^{[78]}>\left[\mathrm{Mo}(\mathrm{Tp}) \mathrm{H}(\mathrm{CO})_{3}\right](-0.53 \mathrm{~V})^{[78]}>\left[\mathrm{Mo}\left(\mathrm{Tp}^{*}\right) \mathrm{H}(\mathrm{CO})_{3}\right](-0.59 \mathrm{~V})^{[78]}\left(\mathrm{Tp}^{*}=\operatorname{hydrotris}(3,5-\right.$ dimethylpyrazolyl)borate) $>\left[\mathrm{Mo}(\mathrm{Cp} *) \mathrm{H}(\mathrm{CO})_{3}\right] \quad(-0.71 \quad \mathrm{~V})^{[78]}$ (values are $v s$. the ferrocene/ferrocinium redox couple). This points out the following order of the electron-donor ability of the involved polyhapto ligands, also in agreement with the IR results discussed above and with the electron donation by the methyl substituents: Tpms $<\mathrm{Cp}<\mathrm{Tp}<\mathrm{Tp} *<$ $\mathrm{Cp}^{*}$.

\section{Conclusion}

This work shows that $\left[\mathrm{Mo}(\mathrm{CO})_{6}\right]$ is a convenient starting material for the syntheses of both low and high oxidation state molybdenum complexes bearing the sulfonated Tpms ligand. In fact, three carbonyls are readily displaced by the Tpms tripodal ligand to afford a tricarbonyl Tpms-Mo ${ }^{0}$ complex (1) which, upon metal halogenation or protonation, forms 7-coordinated Tpms-MoII complexes ( 3 and $\mathbf{5}$ ). The latter are oxidized with air to form high oxidation state dinuclear Tpms-oxo-Mo complexes bearing the $\left\{\mathrm{Mo}_{2} \mathrm{O}_{2}(\mu-\mathrm{O})_{2}\right\}^{2+}$ and $\left\{\mathrm{Mo}_{2} \mathrm{O}_{2} \mathrm{Cl}_{2}(\mu-\mathrm{O})\right\}^{2+}$ moieties, the latter upon chlorination with $\mathrm{CHCl}_{3}$. The Tpms-oxo-Mo ${ }^{\mathrm{VI}}$ complex, on the other hand, contains the $\left\{\mathrm{Mo}_{2} \mathrm{OI}_{4}(\mu-\mathrm{O})\right\}^{2+}$ unit and was obtained by oxidation of the above Tpms$\mathrm{Mo}^{0}$ compound $\mathbf{1}$. Hence, the low oxidation state $\mathrm{Tpms}_{-} \mathrm{Mo}^{0}$ complex provides a versatile entry to a diversity of high oxidation state Tpms-oxo-Mo species.

Interestingly, the sulfonate group of the Tpms ligand is not innocent and plays a determining role on the properties of some of the complexes, not only by imparting hydrosolubility, but 
also by coordinating to the molybdenum atom (in 4) or to the $\mathrm{Li}^{+}$ion of a contiguous molecule forming a 1D polymeric chain (in $\mathbf{2}$ and also in the $[\mathrm{Li}(\mathrm{Tpms})]_{\mathrm{n}}$ salt).

The above features of the sulfonate group of Tpms deserve to be further explored for the syntheses of other water soluble (i) organometallic low oxidation state Mo complexes, (ii) middle and high oxidation state Mo compounds, and (iii) polymeric and supramolecular assemblies.

In addition, the availability of comparable $\mathrm{Tp}, \mathrm{Tp} *, \mathrm{Cp}$ and $\mathrm{Cp}^{*}$ complexes allows the ordering of the corresponding and related polyhapto ligands according to their electron-donor character on the basis of the oxidation potentials of those complexes, as measured by cyclic voltammetry which provides a rather convenient tool for this purpose.

\section{Experimental Section}

\section{General Techniques}

Unless stated otherwise, all preparations and manipulations were carried out with Schlenk techniques under an oxygen-free argon atmosphere. All glassware was oven-dried at $120^{\circ} \mathrm{C}$. Tetrahydrofuran and diethyl ether were dried over $\mathrm{Na} /$ benzophenone, toluene was dried over $\mathrm{Na}$, and pentane and dichloromethane were dried over $\mathrm{CaH}_{2}$. Each of them was distilled under dinitrogen prior to use.

\section{Materials and Instrumentation}

IR spectra were recorded on a BIO-RAD FTS 3000MX spectrophotometer, in KBr pellets. Wavenumbers are in $\mathrm{cm}^{-1}$; abbreviations: vs $=$ very strong, $\mathrm{s}=$ strong, $\mathrm{m}=$ medium, $\mathrm{w}=$ weak br $=$ broad. ${ }^{1} \mathrm{H}$ NMR spectra were recorded on a Bruker Avance II 300, operating at $300 \mathrm{MHz}$. Chemical shifts were measured relative to residual solvent proton resonances and are expressed in ppm downfield from $\mathrm{Me}_{4} \mathrm{Si}$. Coupling constants are given in Hertz. 
Abbreviations: $\mathrm{s}=$ singlet, $\mathrm{d}=$ doublet, $\mathrm{m}=$ complex multiplet; $\mathrm{dd}=$ doublet of doublets, $\mathrm{br}=$ broad.

The electrochemical experiments were performed on an EG\&G PAR 273A potentiostat/galvanostat connected to a personal computer through a GPIB interface. Cyclic voltammograms were obtained in $0.2 \mathrm{M}\left[n \mathrm{Bu}_{4} \mathrm{~N}\right]\left[\mathrm{BF}_{4}\right]$ in $\mathrm{CH}_{2} \mathrm{Cl}_{2}$, at a platinum disc working electrode $(d=1 \mathrm{~mm})$ and at $25{ }^{\circ} \mathrm{C}$. A Luggin capillary connected to a silver wire pseudoreference electrode was used to control the working electrode potential, and a Pt wire was employed as the counter electrode. The redox potentials of the complexes were measured by cyclic voltammetry and their values are quoted relative to the SCE by using the $\left[\mathrm{Fe}\left(\eta^{5}\right.\right.$ $\left.\left.\mathrm{C}_{5} \mathrm{H}_{5}\right)_{2}\right]^{0 /+}$ redox couple $\left(E_{1 / 2}{ }^{\text {ox }}=0.525 \mathrm{~V}\right.$ vs. SCE in $\left.\mathrm{CH}_{2} \mathrm{Cl}_{2}{ }^{[79]}\right)$ as internal standard. Hydrotris(1-pyrazolyl)methane and lithium tris(1-pyrazolyl)methanesulfonate were prepared in accordance with published procedures. ${ }^{[25,80]}$ Mass spectra were recorded with a Varian 500MS LC Ion Trap Mass spectrometer equipped with an electrospray-ionization (ESI) interface. Mass spectra were obtained by scanning the mass analyzer from $\mathrm{m} / \mathrm{z} 50$ to 2000 with a total of 3 microscans. Elemental analyses were carried out at the Analytical Laboratory of the Instituto Superior Técnico, Universidade Técnica de Lisboa.

\section{Preparation of Complexes}

\section{Lithium tricarbonyl\{tris(1-pyrazolyl)methanesulfonato\}molybdenum(0)}

\section{$\mathrm{Li}\left[\mathrm{Mo}(\mathrm{Tpms})(\mathrm{CO})_{3}\right](1)$ and its conversion to $\left[\mathrm{Mo}(\mathrm{Tpms})(\mathrm{CO})_{2}(\mu-\mathrm{CO}) \mathrm{Li}\left(\text { thf }_{2}\right)_{2}\right]_{\mathrm{n}}(2)$}

A suspension of $\left[\mathrm{Mo}(\mathrm{CO})_{6}\right] \quad(0.1420 \quad \mathrm{~g}, \quad 0.538 \quad \mathrm{mmol})$ and lithium tris $(1-$ pyrazolyl)methanesulfonate LiTpms $(0.1774 \mathrm{~g}, 0.591 \mathrm{mmol})$ was refluxed in $\mathrm{CH}_{3} \mathrm{CN}(60 \mathrm{~mL})$ for $6 \mathrm{~h}$ under a dinitrogen atmosphere. The initially white suspension turned into a clear yellow solution and then to green. After cooling to $20^{\circ} \mathrm{C}$, the reaction mixture was filtered in order to remove the unreacted ligand (not very soluble in $\mathrm{CH}_{3} \mathrm{CN}$ ), and the resulting solution was evaporated under reduced pressure affording a yellowish-green powder of $\mathbf{1}$ in 
quantitative yield. Compound 1 is readily soluble in water $\left(S_{25^{\circ} \mathrm{C}} \approx 16 \mathrm{mg} \cdot \mathrm{mL}^{-1}\right)$ and in other polar solvents such as $\mathrm{MeOH}, \mathrm{CH}_{3} \mathrm{CN}$, thf, $\mathrm{CHCl}_{3}$ and $\mathrm{CH}_{2} \mathrm{Cl}_{2} .{ }^{1} \mathrm{H} \mathrm{NMR}\left(300 \mathrm{MHz}, \mathrm{CD}_{3} \mathrm{OD}\right.$, $\left.20^{\circ} \mathrm{C}\right): \delta 8.84\left(\mathrm{~d}, 3 \mathrm{H},{ }^{3} J_{\mathrm{HH}}=3.0 \mathrm{~Hz}, H(5)\right.$ or $H(3)$, pyrazolyl], $7.97\left(\mathrm{~d}, 3 \mathrm{H},{ }^{3} J_{\mathrm{HH}}=1.9 \mathrm{~Hz}\right.$, $H(3)$ or $H(5)$, pyrazolyl), $6.36\left(\mathrm{dd}, 3 \mathrm{H},{ }^{3} \mathrm{~J}_{\mathrm{HH}}=2.9 \mathrm{~Hz}, H(4)\right.$ pyrazolyl). ${ }^{13} \mathrm{C}$ NMR $(75.5 \mathrm{MHz}$, $\mathrm{CD}_{3} \mathrm{OD}, 20^{\circ} \mathrm{C}$ ): $\delta 146.12$ (s, $C(3)$ or $C(5)$, pyrazolyl), 135.86 (s, $C(5)$ or $C(3)$ pyrazolyl), 106.59 (s, C(4), pyrazolyl). IR (KBr pellet): $v(\mathrm{CO})=1916,1756 \mathrm{~cm}^{-1}$. MS (ESI) in $\mathrm{CH}_{3} \mathrm{CN}$ : $m / z 475.3\left(\left[\mathrm{M}^{-}\right]\right)$.

For recrystallization, the above yellowish-green solid of $\mathbf{1}$ was dissolved in thf, whereupon $\mathrm{Et}_{2} \mathrm{O}$ was slowly diffused affording suitable crystals of $\left[\mathrm{Mo}(\mathrm{Tpms})(\mathrm{CO})_{2}(\mu-\mathrm{CO}) \mathrm{Li}(\text { thf })_{2}\right]_{\mathrm{n}}(2)$. Anal. for $\mathrm{MoLiSO}_{6} \mathrm{~N}_{6} \mathrm{C}_{13} \mathrm{H}_{9}$. 2 thf (624.4): calcd. C 40.4, N 13.5, H 4.0; found: C 40.6, N 13.1, H 4.0.

\section{Lithium tris(1-pyrazolyl)methanesulfonate ligand [LiTpms]}

To the unreacted ligand, isolated by filtration (see above) in the synthesis of (1), was added $\mathrm{CH}_{3} \mathrm{CN}(5 \mathrm{~mL})$ and to increase the solubility of the compound, the mixture was heated to $c a$. $85^{\circ} \mathrm{C}$ for $30 \mathrm{~min}$. The hot solution was then filtered to an open flask and slowly cooled to room temperature, affording white crystals of polymeric [LiTpms $]_{n}$ suitable for X-ray analysis.

\section{Tricarbonyliodo\{tris(1-pyrazolyl)methanesulfonato\}molybdenum(II) $\left[\mathrm{Mo}(\mathrm{Tpms}) \mathrm{I}(\mathrm{CO})_{3}\right](3)$}

To a solution of $(\mathbf{1})(0.131 \mathrm{~g}, 0.273 \mathrm{mmol})$ in $\mathrm{CH}_{3} \mathrm{CN}(20 \mathrm{~mL})$ one equivalent of elemental $\mathrm{I}_{2}$ $(0.0693 \mathrm{~g}, 0.273 \mathrm{mmol})$ was added, resulting in a colour change of the reaction mixture from green to reddish-brown. After $1 \mathrm{~h}$, the solution was taken to dryness under vacuum and the resulting reddish-brown solid was extracted with $15 \mathrm{~mL}$ of a 1:1 $\mathrm{CHCl}_{3}$-thf mixture. After filtration, the solution was evaporated under reduced pressure affording a reddish-brown 
powder of 3. Yield: $0.098 \mathrm{~g}(0.164 \mathrm{mmol}, 60 \%)$. Compound 3 is readily soluble in chlorinated hydrocarbons, $\mathrm{CH}_{3} \mathrm{CN}$, thf and also in water $\left(\mathrm{S}_{25^{\circ} \mathrm{C}} \approx 5 \mathrm{mgmL}^{-1}\right)$, not considerably soluble in alcohols, diethyl ether and hydrocarbon solvents. IR ( $\mathrm{KBr}$ pellet): $v(\mathrm{CO})=2039$, 1966, $1944 \mathrm{~cm}^{-1} .{ }^{1} \mathrm{H}$ NMR $\left(300 \mathrm{MHz}, \mathrm{CDCl}_{3}, 20^{\circ} \mathrm{C}\right): \delta 9.17\left(\mathrm{~d}, 3 \mathrm{H},{ }^{3} J_{\mathrm{HH}}=2.9 \mathrm{~Hz}, H(5)\right.$ or $H(3)$, pyrazolyl), $8.51\left(\mathrm{~d}, 3 \mathrm{H},{ }^{3} J_{\mathrm{HH}}=2.2 \mathrm{~Hz}, H(3)\right.$ or $H(5)$, pyrazolyl $), 6.56\left(\mathrm{dd}, 3 \mathrm{H},{ }^{3} J_{\mathrm{HH}}=\right.$ $2.7 \mathrm{~Hz}, H(4)$ pyrazolyl). ${ }^{13} \mathrm{C}$ NMR $\left(75.5 \mathrm{MHz}, \mathrm{CDCl}_{3}, 20^{\circ} \mathrm{C}\right): \delta 148.94[\mathrm{~s}, C(5)$ or $C(3)$ pyrazolyl], 138.08 [s, $C(3)$ or $C(5)$, pyrazolyl], 107.96 [s, $C(4)$, pyrazolyl]. Anal. for $\mathrm{MoSO}_{6} \mathrm{~N}_{6} \mathrm{C}_{13} \mathrm{H} \mathrm{H}_{9} \mathrm{I} \cdot 1.5$ thf $\cdot \mathrm{CHCl}_{3} \cdot 2 \mathrm{H}_{2} \mathrm{O}$ (864.0): calcd. C 27.8, N 9.7, H 3.0; found: C 27.0, N 9.4, H 3.2 .

\section{Tetraoxobis $\{\operatorname{tris}(1-p y r a z o l y l) m e t h a n e s u l f o n a t o\} \operatorname{dimolybdenum}(\mathrm{V})$}

\section{$[\mathrm{Mo}(\mathrm{Tpms}) \mathrm{O}(\mu-\mathrm{O})]_{2}(4)$}

Reddish-brown crystals of $\mathbf{4} \cdot 2 \mathrm{CH}_{3} \mathrm{CN}$ suitable for X-ray analysis were obtained upon slow diffusion of $\mathrm{Et}_{2} \mathrm{O}$ into a $\mathrm{CH}_{3} \mathrm{CN}$ solution of complex (3). IR (KBr): 1104, 1073, 1056, 1032 (br, s, $\mathrm{S}=\mathrm{O}, \mathrm{Mo}=\mathrm{O}$ ), $803 \mathrm{~cm}^{-1}$ (s, Mo-O-Mo). ${ }^{1} \mathrm{H}$ NMR $\left(300 \mathrm{MHz},\left(\mathrm{CD}_{3}\right)_{2} \mathrm{CO}, 20^{\circ} \mathrm{C}\right): \delta 9.19$ (m, 6H, H(5) or $\mathrm{H}(3)$, pyrazolyl], 7,53 (m, 6H, H(3) or $\mathrm{H}(5)$, pyrazolyl), $6.63(\mathrm{~m}, 6 \mathrm{H}, \mathrm{H}(4)$ pyrazolyl). ${ }^{13} \mathrm{C} \mathrm{NMR}\left(75.5 \mathrm{MHz},\left(\mathrm{CD}_{3}\right)_{2} \mathrm{CO}, 20^{\circ} \mathrm{C}\right): \delta 167.59$ [s, 3C, $\mathrm{C}(5)$ or $\mathrm{C}(3)$ pyrazolyl], 145.23 [s, 3C, C(3) or C(5), pyrazolyl], 95,10 [s, 3C, C(4), pyrazolyl].

\section{Tricarbonylhydrido\{tris(1-pyrazolyl)methanesulfonato\}molybdenum(II) $\left[\mathrm{Mo}(\mathrm{Tpms}) \mathrm{H}(\mathrm{CO})_{3}\right](\mathbf{5})$.}

Complex (1) (130 mg, $0.2715 \mathrm{mmol})$ was dissolved in $\mathrm{CH}_{3} \mathrm{CN}(30 \mathrm{~mL})$ at $20{ }^{\circ} \mathrm{C}$. $\mathrm{HBF}_{4}(69.42$ $\mu \mathrm{L}, 54 \%$ in diethyl ether, $0.5068 \mathrm{mmol}$ ) was added dropwise, resulting in a colour change of the reaction mixture from greenish-yellow to green. After $1 \mathrm{~h}$, the reaction mixture was taken to dryness under vacuum and the resulting solid was extracted with $5 \mathrm{~mL}$ of distilled $\mathrm{CH}_{3} \mathrm{COCH}_{3}$. The suspension was filtered and the resulting solution was evaporated under 
reduced pressure affording (5) as a green powder. Yield: $0.085 \mathrm{~g}(0.18 \mathrm{mmol}, 66 \%)$. Compound $\mathbf{5}$ is soluble in acetonitrile and chloroform and sparingly soluble in water $\left(S_{25^{\circ} \mathrm{C}} \approx 1\right.$ $\left.\mathrm{mg} \cdot \mathrm{mL}^{-1}\right)$. IR $(\mathrm{KBr}$ pellet $): v(\mathrm{CO})=2025,1945,1912 \mathrm{~cm}^{-1} \cdot{ }^{1} \mathrm{H} \mathrm{NMR}\left(300 \mathrm{MHz}, \mathrm{CDCl}_{3}\right.$, $\left.20^{\circ} \mathrm{C}\right): \delta 9.05\left(\mathrm{~d}, 3 \mathrm{H},{ }^{3} J_{\mathrm{HH}}=2.9 \mathrm{~Hz}, H(5)\right.$ or $H(3)$, pyrazolyl $], 8.08\left(\mathrm{~d}, 3 \mathrm{H},{ }^{3} J_{\mathrm{HH}}=2.2 \mathrm{~Hz}\right.$, $H(3)$ or $H(5)$, pyrazolyl), $6.46\left(\mathrm{dd}, 3 \mathrm{H},{ }^{3} J_{\mathrm{HH}}=2.7 \mathrm{~Hz}, H(4)\right.$ pyrazolyl $),-3.23(\mathrm{~s}, 1 \mathrm{H}, \mathrm{MoH})$. ${ }^{13} \mathrm{C} \mathrm{NMR}\left(75.5 \mathrm{MHz}, \mathrm{CDCl}_{3}, 20^{\circ} \mathrm{C}\right): \delta 147.42$ [s, $C(5)$ or $C(3)$ pyrazolyl], 137.24 [s, $C(3)$ or $C(5)$, pyrazolyl], 107.36 [s, $C(4)$, pyrazolyl]. MS (ESI) in $\mathrm{CH}_{3} \mathrm{CN}: m / z 475.3$ ([M-1). Anal. for $\mathrm{MoSO}_{6} \mathrm{~N}_{6} \mathrm{C}_{13} \mathrm{H}_{10} \cdot 2 \mathrm{CH}_{3} \mathrm{COCH}_{3}$ (590.4): calcd. C 38.7, N 14.2, H 3.7; found: C 38.8, N 14.0, H 3.5.

\section{Dichlorotrioxobis\{tris(1-pyrazolyl)methanesulfonato $\} \operatorname{dimolybdenum(V)}$ $[\mathrm{Mo}(\mathrm{Tpms}) \mathrm{OCl}]_{2}(\mu-\mathrm{O})(6)$}

Reddish-brown crystals of $\mathbf{6} \cdot 6 \mathrm{CHCl}_{3}$ suitable for $\mathrm{X}$-ray analysis were obtained, in the presence of air, by slow evaporation of a chloroform solution of complex (5). IR (KBr): 1095, 1079, 1057, 1030 (br, s, S=O, Mo=O), $802 \mathrm{~cm}^{-1}$ (s, Mo-O-Mo).

\section{Pentaoxobis\{tris(1-pyrazolyl)methanesulfonato\}dimolybdenum(VI)}

$\left[\mathrm{Mo}(\mathrm{Tpms}) \mathrm{O}_{2}\right]_{2}(\mu-\mathrm{O})(7)$

$\mathrm{AgBF}_{4}(40.5 \mathrm{mg}, 0.208 \mathrm{mmol})$ was dissolved in thf $(10 \mathrm{~mL})$ and added to a thf solution (10 $\mathrm{mL})$ of $1(100 \mathrm{mg}, 0.208 \mathrm{mmol})$ at $20^{\circ} \mathrm{C}$. The colour of the reaction mixture immediately changed from green to red and a black solid (Ag) started to precipitate. The suspension was filtered and the resulting reddish solution was evaporated under reduced pressure affording a reddish brown powder. This crude solid was washed with $2 \times 10 \mathrm{~mL}$ of $\mathrm{CH}_{3} \mathrm{CN}$, dried under vacuum. Slow diffusion of $\mathrm{Et}_{2} \mathrm{O}$ into a thf solution of this crude solid afforded, in the presence of air, yellow crystals of 7·thf that were suitable for X-ray analysis. IR (KBr): 1080, 1070, 1040 (br, s, S=O, Mo=O), 916 (w, M=O), $801 \mathrm{~cm}^{-1}$ (s, Mo-O-Mo). 
Crystal Structure Determinations. Single crystals of $[\mathrm{LiTpms}]_{\mathrm{n}}, \mathbf{2 ,}$, 6 and 7 were obtained as indicated above. Intensity data were collected at $150 \mathrm{~K}$, using a Bruker AXS-KAPPA APEX II diffractometer with graphite monochromated Mo-K $\alpha(\lambda$ 0.71073) radiation. Data were collected using omega scans of $0.5^{\circ}$ per frame and full sphere of data were obtained. Cell parameters were retrieved using Bruker SMART software and refined using Bruker SAINT ${ }^{[81]}$ on all the observed reflections. Absorption corrections were applied using SADABS. ${ }^{[81]}$ Structures were solved by direct methods by using the SHELXS-97 package ${ }^{[82]}$ and refined with SHELXL-97. ${ }^{[83]}$ Calculations were performed using the WinGX System-Version 1.80.03. ${ }^{[84]}$ All hydrogen atoms were inserted in calculated positions. Least-squares refinements with anisotropic thermal motion parameters for all the non-hydrogen (except $\mathrm{C} 17, \mathrm{~N} 22$ and $\mathrm{N} 27$ of [LiTpms $]_{\mathrm{n}}$ which were refined isotropically) atoms and isotropic for the remaining atoms were employed. atoms and isotropic ones for the remaining atoms were employed. Crystal data and refinement parameters are shown in Table 1. CCDC numbers 749680 to 749684 contain the supplementary crystallographic data for this paper. These data can be obtained free of charge from the Cambridge Crystallographic Data Centre via www.ccdc.cam.ac.uk/data_request/cif.

\section{Acknowledgements}

We are grateful to the European Commission for funding of this work through the AQUACHEM research Training Network (Project $n^{\circ}$ MRTN-CT-2003-503864). This study has been also supported by the Foundation for Science and Technology (FCT) and its POCI 2010 and PPCDT programmes (FEDER funded), grant BPD/20869/04. The authors also thank to Dr. M. Cândida Vaz and Dr. Conceição Oliveira for the elemental analysis and ESIMS services, respectively. 
Table 1. Selected crystallographic and refinement parameters for compounds [LiTpms $]_{n}, 2,4.2 \mathrm{CH}_{3} \mathrm{CN}, \mathbf{6 . 6 C H C l} 3$ and 7.thf.

\begin{tabular}{|c|c|c|c|c|c|}
\hline Compound & {$[\mathrm{LiTpms}]_{\mathrm{n}}$} & 2 & $4.2 \mathrm{CH}_{3} \mathrm{CN}$ & 6.6 $\mathrm{CHCl}_{3}$ & 7.thf \\
\hline Empirical formula & $\mathrm{C}_{20} \mathrm{H}_{18} \mathrm{Li}_{2} \mathrm{~N}_{12} \mathrm{O}_{6} \mathrm{~S}_{2}$ & $\mathrm{C}_{21} \mathrm{H}_{25} \mathrm{Li} \mathrm{Mo} \mathrm{N}_{6} \mathrm{O}_{8} \mathrm{~S}$ & $\mathrm{C}_{24} \mathrm{H}_{24} \mathrm{Mo}_{2} \mathrm{~N}_{14} \mathrm{O}_{10} \mathrm{~S}_{2}$ & $\mathrm{C}_{26} \mathrm{H}_{24} \mathrm{Cl}_{20} \mathrm{Mo}_{2} \mathrm{~N}_{12} \mathrm{O}_{9} \mathrm{~S}_{2}$ & $\mathrm{C}_{24} \mathrm{H}_{26} \mathrm{Mo}_{2} \mathrm{~N}_{12} \mathrm{O}_{12} \mathrm{~S}_{2}$ \\
\hline Formula weight & 600.46 & 624.42 & 924.57 & 1613.57 & 930.57 \\
\hline Crystal system & orthorhombic & Triclinic & Monoclinic & Monoclinic & Monoclinic \\
\hline Space group & P c a 21 & $\mathrm{P}-1$ & $\mathrm{C} 2 / \mathrm{c}$ & $\mathrm{P} 21 / \mathrm{c}$ & $\mathrm{P} 21 / \mathrm{n}$ \\
\hline$a(\AA)$ & $18.6055(15)$ & $10.469(2)$ & $18.3013(5)$ & $12.157(2)$ & $13.222(3)$ \\
\hline$b(\AA)$ & $8.3363(9)$ & $10.794(2)$ & $13.4344(4)$ & $12.716(3)$ & $19.685(4)$ \\
\hline$c(\AA)$ & $16.6854(14)$ & $11.685(4)$ & $15.2516(4)$ & $18.007(4)$ & $14.048(3)$ \\
\hline$\alpha\left(^{\circ}\right)$ & 90 & $90.156(17)$ & 90 & 90 & 90 \\
\hline$\beta\left(^{\circ}\right)$ & 90 & $99.50(2)$ & $116.8860(10)$ & $99.255(13)$ & $117.084(5)$ \\
\hline$\gamma\left({ }^{\circ}\right)$ & 90 & $94.365(18)$ & 90 & 90 & 90 \\
\hline Volume $\left(\AA^{3}\right)$ & $2587.9(4)$ & $1298.4(6)$ & $3344.53(16)$ & $2747.6(10)$ & $3255.4(12)$ \\
\hline $\mathrm{Z}$ & 4 & 2 & 4 & 2 & 4 \\
\hline Density (calculated) $\left(\mathrm{Mg} / \mathrm{m}^{3}\right)$ & 1.541 & 1.597 & 1.836 & 1.950 & 1.899 \\
\hline Absorption coefficient $\left(\mathrm{mm}^{-1}\right)$ & 0.269 & 0.642 & 0.951 & 1.563 & 0.981 \\
\hline $\mathrm{F}(000)$ & 1232 & 636 & 1848 & 1584 & 1864 \\
\hline Rfls collected & 11746 & 17721 & 8097 & 16985 & 14365 \\
\hline Unique rfls. & 4493 & 4576 & 3045 & 5004 & 4725 \\
\hline Rint & 0.1589 & 0.1106 & 0.0329 & 0.2844 & 0.0418 \\
\hline GOF & 0.935 & 0.964 & 1.061 & 0.954 & 1.037 \\
\hline Final $R_{1}, w R_{2}(I \geq 2 \sigma)^{[\mathrm{a}]}$ & $0.0775,0.1636$ & $0.0538,0.1016$ & $0.0280,0.0681$ & $0.0949,0.1676$ & $0.0357,0.0864$ \\
\hline$R_{1}, w R_{2}$ (all data) & $0.1577,0.2151$ & $0.1016,0.1189$ & $0.0364,0.0717$ & $0.2572,0.2349$ & $0.0465,0.0920$ \\
\hline
\end{tabular}

[a] $R_{1}=\Sigma|| F_{\mathrm{o}}|-| F_{\mathrm{c}}|/ \Sigma| F_{\mathrm{o}} \mid ; w R_{2}=\left[\Sigma\left[w\left(F_{\mathrm{o}}^{2}-F_{\mathrm{c}}{ }^{2}\right)^{2}\right] / \Sigma\left[w\left(F_{\mathrm{o}}\right)^{2}\right]\right]^{1 / 2}$. 


\section{References}

[1] S. Trofimenko, Scorpionates - The Coordination Chemistry of Poly(pyrazolyl)borate Ligands, Imperial College Press, London, 1999.

[2] C. Pettinari, Scorpionates II - Chelating Borate Ligands, Imperial College Press, London, 2008.

[3] C. Pettinari, C. Santini in Comprehensive Coordination Chemistry II, vol. 1, eds. J. A. McCleverty and T. J. Meyer, Elsevier, Oxford, 2004, Ch. 10, p. 159.

[4] R. Garcia, A. Paulo, I. Santos, Inorg. Chim. Acta 2009, 12, 4315.

[5] C. Pettinari, R. Pettinari, Coord. Chem. Rev. 2005, 249, 525.

[6] C. Pettinari, R. Pettinari, Coord. Chem. Rev. 2005, 249, 663.

[7] H. R. Bigmore, S. C. Lawrence, P. Mountford, C. S. Tredget, Dalton Trans. 2005, 635.

[8] S. Trofimenko, Polyhedron 2004, 23, 197.

[9] M. Etienne, Coord. Chem. Rev. 1996, 156, 201.

[10] S. Trofimenko, Chem. Rev. 1993, 93, 943.

[11] A. Otero, J. Fernández-Baeza, A. Antiñolo, J. Tejeda, A. Lara-Sanchéz, J. Chem.Soc. Dalton 2004, 1499.

[12] J. M. Smith, Comment Inorg. Chem. 2008, 29, 189.

[13] H. V. R. Dias, T. K. H. H. Goh, Polyhedron. 2004, 23, 273.

[14] S. Trofimenko, J. Am. Chem. Soc. 1967, 89, 3170.

[15] S. Trofimenko, J. Am. Chem. Soc. 1967, 89, 6288.

[16] A. Paulo, J. D .G. Correia, M. P. C. Campello, I. Santos, Polyhedron 2004, 23, 331.

[17] I. Santos, A. Paulo, J. D. G. Correia, Top. Curr. Chem. 2005, 252, 45.

[18] X. Hu, K. Meyer, J. Organomet. Chem. 2005, 690, 5474.

[19] D. Buccella, A. Shultz, J. G. Melnick, F. Konopka, G. Parkin, Organometallics 2006, 25, 5496. 
[20] P. J. Bailey, D. J. Lorono-Gonzales, C. McCormack, S. Parsons, M. Price, Inorg. Chim. Acta. 2003, 354, 61.

[21] L. A. Graham, A. R. Fout, K. R. Kuchne, J. L. White, B. Mookherji, F. M. Marks, G. P. A. Yap, L. N. Zakharov, A. L. Rheingold, and D. Rabinovich, Dalton Trans. 2005, 171.

[22] L. S. Maffett, K. L. Gunter, K. A. Kreisel, G. P. A. Yap, D. Rabinovich, Polyhedron 2007, 26, 4758 .

[23] M. R. S.-J. Foreman, A. F. Hill, A. J. P. White, D. J. Williams, Organometallics 2003, 22,3831 .

[24] J. C. Calabrese, S. Trofimenko, J. S. Thompson, J. Chem. Soc., Chem. Commun. 1986, 1122

[25] W. Kläui, M. Berghahn, G.. Rheiwald, H. Lang, Angew. Chem. 2000, 112, 2590. (b) W. Kläui, M. Berghahn, G. Rheiwald, H. Lang, Angew. Chem. 2000, 39, 2464.

[26] T. F. S. Silva, E. C. B. A. Alegria, L. M. D. R.S. Martins, A. J. L. Pombeiro, Adv. Synth. Catal. 2008, 350, 706.

[27] E.C.B. Alegria , L.M.D.R.S. Martins, M. Haukka, A.J.L. Pombeiro, Dalton Trans. 2006, 4954.

[28] R. Wanke, P. Smolenski, M. F. C. Guedes da Silva, L. M. D. R. S. Martins, A. J. L. Pombeiro, Inorg. Chem. 2008, 47, 10158.

[29] G. S. Mishra, E. C. B. Alegria, L. M. D. R. S. Martins, A. J. L. Pombeiro, J. Mol. Catal. A: Chem. 2008, 285, 92.

[30] E. C. B. Alegria, M. V. Kirillova, L. M. D. R. S. Martins, A. J. L. Pombeiro, Appl. Cat. A: Gen. 2007, 317, 43.

[31] G. S. Mishra, T. F. S. Silva, L. M. D. R. S. Martins, A. J. L. Pombeiro, Pure Appl. Chem. 2009, 81, 1217.

[32] S. M. P. R. M. Cunha, M. F. C. Guedes da Silva, J. J. R. Fraústo da Silva, A. J. L. Pombeiro, Eur. J. Inorg. Chem. 2009, 3966. b) N. C. T. Martins, M. F. C. Guedes da Silva, R. 
Wanke, A. J. L. Pombeiro, Dalton Trans. 2009, 4772. c) L. M. D. R. S. Martins, E. C. B. A. Alegria, D. L. Hughes, J. J. R. Fraústo da Silva, A. J. L. Pombeiro, Dalton Trans. 2003, 3743. d) S. M. P. R. Cunha, M. F. C. Guedes da Silva, A. J. L. Pombeiro, Inorg. Chem. 2003, 42, 2157. e) S. M. P. R. M. Cunha, M. F. C. Guedes da Silva, A. J. L. Pombeiro, J. Chem. Soc., Dalton Trans. 2002, 1791. f) A. J. L. Pombeiro, New J. Chem. 1994, 18, 163. g) M. V. Kirillova, J. A. L. da Silva, J. J. R. Fraústo da Silva, A. J. L. Pombeiro, Appl. Cat. A: Gen., 2007, 332, 159. h) M. V. Kirillova, A. M. Kirillov, P. M. Reis, J. A. L. Silva, J. J. R. Fraústo da Silva, A. J. L. Pombeiro, J. Cat., 2007, 248, 130.

[33] a) M. Baya, P. A. Dub, J. Houghton, J-C. Daran, N. V. Belkova, E. S. Shubina, L. M. Epstein, A. Lledos, R. Poli, Inorg. Chem. 2009, 48, 209. b) N. V. Belkova, M. Besora, M. Baya, P. A. Dub, L. M. Epstein, A. Lledos, R. Poli, P. O. Revin, E. S. Shubina, Chem. A. Eur. Journ. 2008, 14, 9921. c) R. Poli, Coord. Chem. Rev. 2008, 252, 1592. d) C. Dinoi, P. Sozen, G. Taban, D. Dernir, F. Dermirhan, P. Prikhodchenko, J. Gun, O. Lev. J-C. Daran, R. Poli, Eur. J. Inorg. Chem. 2007, 4306.

[34] S. Trofimenko, J. Am. Chem. Soc. 1970, 92, 5118.

[35] I. K. Dhawan, M. A. Bruck, B. Schilling, C. Grittini, J. H. Enemark, Inorg. Chem. 1995, 34,3801 .

[36] A. Sánchez-Mendez, A. M. Ortiz, E. de Jesus, J. C. Flores, P. Gomez-Sal, Dalton Trans. 2007, 48,5658 .

[37] A. M. Santos, F. E. Kuhn, K. Bruus-Jensen, I. Lucas, C. C. Romão, E. Herdtweck, J. Chem. Soc. Dalton Trans. 2001, 1332.

[38] S. Dilsky, J. Organomet. Chem. 2007, 692, 2887.

[39] F. A. Cotton, C. S. Kraihanzel, J. Am. Chem. Soc., 1962, 84, 4432.

[40] R. Birdwhistell, P. Hackett, A.R. Manning, J. Organomet. Chem. 1978, 157, 239.

[41] M. D. Curtis, K.-B.Shiu, Inorg. Chem. 1985, 24, 1213.

[42] C. G. Young, S. Thomas, R. W. Gable, Inorg. Chem. 1998, 37, 1299. 
[43] M. G. B. Drew, P. K. Baker, E. M. Armstrong, S. G. Fraser, D. J. Muldoon, A. J. Lavery, A. Shawcross, Polyhedron 1995, 14, 617.

[44] M. Cindrić, G. Galin, D. Matković-Calogović, P. Novak, T. Hrenar, I. Ljubić, T. Kajfež Novak , Polyhedron 2009, 28, 562

[45] A. Dolbecq, J. D. Compain, P. Mialane, M. Pierre, J. Marrot, F. Secheresse, B. Keita, L. R. B. Holzle, F. Miserque, Frederic, L. Nadjo, Chem. Eur. J. 2009, 15, 733.

[46] R. Aguado, J. Escribano, M. R. Pedrosa, A. De Cian, R. Sanz , F. J. Arnáiz, Polyhedron 2007, 26, 3842

[47] B. Modec, Inorg. Chim. Acta, 2008, 361, 2863.

[48] Z. H. Zhou, Y. F. Zhou, Z. X. Cao, R. H. Zhang, Y. L. Chow, Inorg. Chem. 2005, 44, 6912.

[49] M. H. Chisholm, K. Folting, J. C. Huffman, C. C. Kirkpatrick, J. Leonelli, Inorg. Chem. 1984, 23, 1021 .

[50] H. Arzoumanian, A. Baldy, M. Pierrot, J. -F. Petrignani, J. Organomet. Chem. 1985, 294, 327.

[51] C. Couldwell, K. Prout, Acta Crystallogr. 1978, B 34, 933-934.

[52] P. Chaudhuri, K. Wieghardt, Y.-H Tsai, C. Kruger, Inorg. Chem. 1984, 23, 427.

[53] A. J. M. Caffyn, S. G. Feng, A. Dierdorf, A. S. Gamble, P. A. Eldredge, M. R. Vossen, P. S. White, J. L. Templeton, Organometallics 1991, 10, 2842.

[54] O. P. Siclovan, R. J. Angelici, Inorg. Chem. 1998, 37, 432.

[55] M. V. Baker, M. R. North, B. W. Skelton, A. H. White, Inorg. Chem. 1999, 38, 4515.

[56] S. Lincoln, S. A. Koch, Inorg. Chem. 1986, 25, 1594.

[57] A. L. Rheingold, J. R. Harper, J. Organometal. Chem. 1991, 403, 335.

[58] D. Saurenz, F. Demirhan, P. Richard, R. Poli, H. Sitzmann, Eur. J. Inorg. Chem. 2002, 1415. 
[59] P. Leoni, M. Pasquali, L. Salsini, C. Di Bugno, D. Braga, P. Sabatino, J. Chem. Soc. Dalton Trans. 1989, 155.

[60] J. W. Faller, Y. Ma, J. Organometal. Chem. 1988, 340, 59.

[61] J. C. Fettinger, D. W. Keogh, R. Poli, J. Am. Chem. Soc. 1996, 118, 3617.

[62] E. A.Quadrelli, H.-B. Kraatz, R. Poli, Inorg. Chem. 1996, 35, 5154.

[63] A. I. F. Venâncio, M. L. Kuznetsov, M. F. C. Guedes da Silva, L. M. D. R. S. Martins, J. J. R. Fraústo da Silva, A. J. L. Pombeiro, Inorg. Chem. 2002, 41, 6456.

[64] S. S. P. R. Almeida, M. F. C. Guedes da Silva, J. J. R. Fraústo da Silva, A. J. L. Pombeiro, J. Chem. Soc., Dalton Trans. 1999, 467.

[65] M. A. N. D. A. Lemos, A. J. L. Pombeiro, J. Organomet. Chem. 1987, 332, C17.

[66] A. J. L. Pombeiro, Eur. J. Inorg. Chem. 2007, 1473.

[67] A. J. L. Pombeiro, J. Organometal. Chem. 2005, 690, 6021.

[68] A. B. P. Lever, Inorg. Chem. 1991, 29, 271.

[69] J. Chatt, C. T. Kan, G. J. Leigh, C. J. Pickett, D. R. Stanley, J. Chem. Soc., Dalton Trans. 1980, 2032.

[70] T. Beissel, B. S. P. C. Della Vedova, K. Wieghardt, R. Boese, Inorg. Chem. 1990, 29, 1736.

[71] I. K. Dhawan, M. A. Bruck, B. Schilling, C. Grittini, J. H. Henemark, Inorg. Chem. 1995, 34,3801 .

[72] G. Backes-Dahmann, W. Herrmann, K. Wieghardt, J. Weiss, Inorg. Chem. 1985, 24, 485.

[73] M. E. N. P. R. A. Silva, A. J. L. Pombeiro, J. J. R. Fraústo da Silva, R. Herrmann, N. Deus, T. J. Castilho, M. F. C. G. Silva, J. Organometal. Chem. 1991, 421, 75.

[74] F. Marchetti, C. Pettinari, R. Pettinari, A. Cerquetella, A. Cingolani, E. J. Chan, K. Kozawa, B. W. Skelton, A. H. White, R. Wanke, M. L. Kuznetsov, L. M. D. R. S. Martins, A. J. L. Pombeiro, Inorg. Chem. 2007, 46, 8245. 
[75] E. Reisner, V. B. Arion, M. F. C. Guedes da Silva, R. Lichtenecker, A. Eichinger, B. K. Keppler, V. Yu. Kukushkin, A. J. L. Pombeiro, Inorg. Chem. 2004, 43, 7083.

[76] A. M. Trzeciak, B. Borak, Z. Ciunik, J. J. Ziólkowski, M. F. C. Guedes da Silva, A. J. L. Pombeiro, Eur. J. Inorg. Chem. 2004, 1411.

[77] E. C. B. Alegria, L. M. D. R. S. Martins, M. F. C. Guedes da Silva, A. J. L. Pombeiro, J. Organomet. Chem. 2005, 690, 4954.

[78] J. D. Protasiewicz, K. H. Theopold, J. Am. Chem. Soc. 1993, 115, 5559.

[79] A. J. L. Pombeiro, M. F. C. Guedes da Silva, M. A. N. D. A. Lemos, Coord. Chem. Rev. 2001, 53, 219.

[80] D. L. Reger, T. C. Grattan, K. J. Brown, C. A. Little, J. J. S. Lamba, A. L. Rheingold, R. D. Sommer, J. Organomet. Chem. 2000, 607, 120.

[81] Bruker, APEX2 \& SAINT. Bruker, AXS Inc., Madison, Wisconsin, USA, 2004.

[82] G. M. Sheldrick, Acta Crystallogr. Sect. A, 1990, 46, 467.

[83] G. M. Sheldrick, Acta Crystallogr. Sect. A, 2008, 112-122.

[84] L. J. Farrugia, J. Appl. Crystallog. 1999, 32, 837. 